\title{
ARTEFACTUALISM AS AN ONTOLOGY OF ART
}

\author{
By \\ Alistair Hamel
}

\begin{abstract}
A thesis
submitted to the Victoria University of Wellington in fulfilment of the requirement for the degree of Master of Arts in Philosophy
\end{abstract}

Victoria University of Wellington 


\begin{abstract}
This thesis argues for artefactualism about works of art, which is the claim that works of art are artefacts. It does this by considering the cases of works of music, and works of fiction, and arguing that each of these are artefacts, or existent, created, individual entities. To do this, it argues against anti-realist, eternalist, and type theories in these domains. The thesis draws on arguments made by philosophers such as Amie Thomasson regarding fictional characters and Guy Rohrbaugh regarding repeatable works of art.
\end{abstract}


Table of Contents

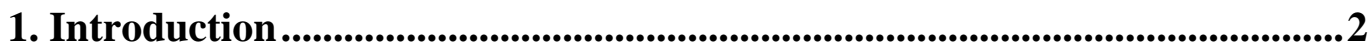

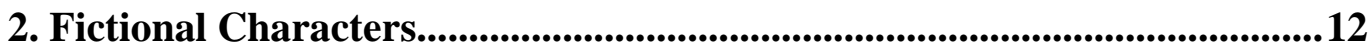

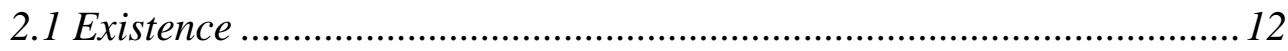

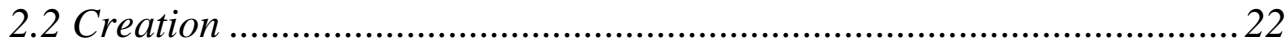

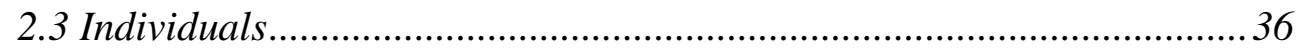

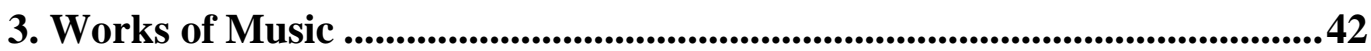

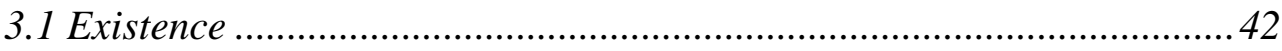

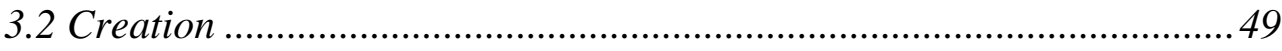

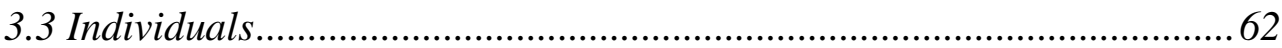

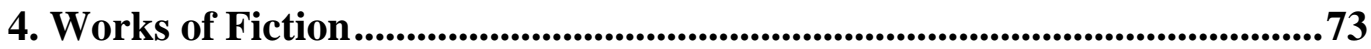

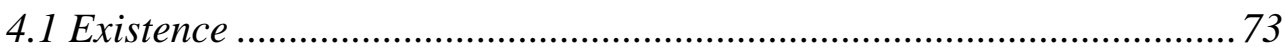

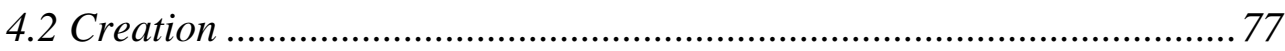

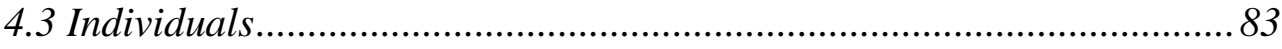

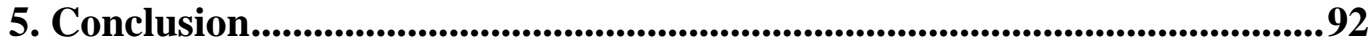

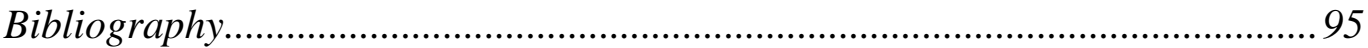




\section{Introduction}

This thesis will argue for the artefactual theory of artworks, according to which works of art are artefacts. Artefacts are contingently existing objects created by particular intentional acts. The claim that artworks are artefacts may not seem to be a surprising claim. Paintings and sculptures, for instance, clearly seem to be man-made physical objects, so no argument should be necessary in support of the claim that they are artefacts. ${ }^{1}$ Nonetheless, there are some works of art that are not so obviously artefacts. Works of music and fiction fall into this category. To see why, consider one popular argument against this view.

1. Works of music and fiction are not identifiable with any particular physical object.

2. Therefore, works of music and fiction are abstract objects. (From 1)

3. Artefacts are, by definition, created.

4. Abstract objects are impossible to create.

5. Therefore, works of music and fiction are not artefacts.

My thesis will demonstrate why this argument is not sound. In particular I will show that the final premise of the argument is flawed. Abstract objects, I maintain, can be and often are created. Amie Thomasson ${ }^{2}$ argues convincingly for this claim with respect to fictional characters, ${ }^{3}$ and her arguments can be

\footnotetext{
${ }^{1}$ But see Gregory Currie, An Ontology of Art (New York: St. Martin's Press, 1989) for an opposing view. Here, Currie argues for an action-type view of paintings. His theory, though, is a minority view, accepted by few philosophers.

${ }^{2}$ Amie L. Thomasson, Fiction and Metaphysics (Cambridge; New York: Cambridge University Press, 1999)

${ }^{3}$ To make it clear, I am not claiming that fictional characters are works of art, but that they have relevant similarities to them.
} 
adapted to cover works of music and of fiction. As a consequence, the second chapter of the thesis will closely examine Thomasson's arguments so they might be extended to cover works of music and fiction in chapters three and four.

Of course, demonstrating that one argument against artefactualism is unsound does not by itself give a reason to think that artefactualism is true. So, chapters two, three, and four also attempt to motivate the view that artefactualism is true of the respective domains. Even if it is successfully shown (as I attempt in chapters three and four) that works of music and of fiction are artefacts, this is not sufficient to demonstrate that all works of art are artefacts. Going through all works of art, case by case, to provide such demonstrations is beyond the scope of this thesis. By picking what I consider to be two of the more controversial cases, though, I hope to have advanced the case significantly.

There are three important aspects of an artefactual theory which distinguishes it from other metaphysical theories: artefacts exist; they are created; and they are individuals. These aspects can each be discussed in relation to fictional objects and works of art.

First, artefacts exist. There are such things as works of art, and as fictional characters. That artefacts exist is presumably implied by the other claims I will make about artefacts, but is worth presenting separately. In the case of paintings an existence claim is entirely uncontroversial: no-one except the most extreme 
global anti-realist seriously suggests that the Mona Lisa does not exist. ${ }^{4}$ It seems to be a concrete object that we can see if we are appropriately positioned. Works of music and novels are also intuitively held to exist. Regardless of whether we have any clear idea of what Beethoven's symphonies, or War and Peace, are, it would be rather surprising to be told that they do not exist. Fictional characters present a different case. We generally have a strong intuition that Sherlock Holmes does not exist, and the artefactualist must explain this away. To do this it will be shown (following Peter van Inwagen) ${ }^{5}$ how our ordinary beliefs about fictional characters do ontologically commit us to them. For instance, the sentence 'Sherlock Holmes is a fictional character' is unhesitatingly taken to be true by most of us, and this sentence entails that something (namely, Sherlock Holmes) is a fictional character. If there is something (some fictional character) identical to Sherlock Holmes, then Sherlock Holmes exists. It will also be suggested how non-existence statements about fictional characters may be paraphrased away, and, even if these paraphrases do not ultimately succeed, how no other theory can adequately deal with non-existence statements either.

Showing that fictional characters do exist will also require responding to pretense theory ${ }^{6}$ and prefix fictionalism ${ }^{7}$ about fictional characters.

Second, artefacts are created. Artists, authors, and composers create paintings, fictional characters, and symphonies. Jerrold Levinson describes this as 'one of

\footnotetext{
${ }^{4}$ See Stuart Brock and Edwin Mares, Realism and Anti-Realism (Stocksfield: Acumen, 2007), chapters 4-6, for a discussion of global anti-realist positions

${ }^{5}$ Peter van Inwagen, 'Creatures of Fiction', American Philosophical Quarterly, vol. 14, no. 4, October 1977, pp. 299-308

${ }^{6}$ Kendall Walton, Mimesis as Make-Believe: On the Foundations of the Representational Arts (Cambridge, MA: Harvard University Press, 1990)

${ }^{7}$ Stuart Brock, 'Fictionalism about Fictional Characters', Nous, vol. 36, no. 1, 2002, pp. 1-21
} 
the most firmly entrenched of our beliefs concerning art. ${ }^{8}$ We do intuitively think that works of art are created by artists. It is again seemingly philosophically uncontroversial that paintings are created. The Mona Lisa did not exist before da Vinci put paint on a canvas, and did exist when he had completed the painting. He thus brought the Mona Lisa into existence, which is to say that he created it. ${ }^{9}$ However, philosophers have tended to be less certain about the creation of music and fiction. The reason for this is the commonly-held belief that fictions and works of music are abstract objects. Abstract objects are objects which do not have both a spatial and a temporal location. ${ }^{10}$ Abstracta are generally regarded to be necessary existents which are causally unconnected to us, and are therefore unable to be created. Platonist theories of abstract works of art do all seek to account for our belief that they are created. They most commonly make recourse to a creative discovery account, in which the work is literally discovered somewhere in logical space, and the artist is correctly held to be creative for doing so. To argue for the claim that fictional characters and works of art are created, two things will be done. The first is to show that any objects which are not created are not the right kinds of thing to be fictional characters and to motivate creationism by explaining the role of creation in the correct individuation of fictional characters and works of music or fiction. The second is to give an account of how it is that these abstract objects can be created. This account will draw heavily on the ideas of Stephen Schiffer ${ }^{11}$ on the importance

\footnotetext{
${ }^{8}$ Jerrold Levinson, 'What a Musical Work Is', The Journal of Philosophy, vol. 77, no. 1, January 1980, p. 8

${ }^{9}$ Whether creation means (or even merely implies) 'bringing into existence' is questioned by Harry Deutsch in Harry Deutsch, 'The Creation Problem', Topoi, vol. 10, no. 2, September 1991, pp. 209-225

${ }^{10}$ This is David Lewis' Way of Negation. David Lewis, On the Plurality of Worlds (Oxford: Basil Blackwell, 1985), pp. 83-84

${ }^{11}$ Stephen Schiffer, 'Language-Created Language-Independent Entities', Philosophical Topics, vol. 24, no. 1, Spring 1996, pp. 149-167
} 
of our social practices in the creation of fictional characters. Though this creation does begin with the author's writing of a text featuring that character, it requires more than this. In particular, this account of the creation of works of art relies on there being a practice of acting in a certain way, and being prepared to make certain statements and hold certain beliefs about works of art. The account of creation defended here will differ from Jerrold Levinson's modified Platonist account of creation as ‘indication' ${ }^{12}$ Levinson's account of creation is very similar to the creative discovery account, though he argues that his account allows for literal creation.

Third, artefacts are individuals. Works of art and fictional characters are not types, or kinds, or properties. They cannot be predicated of any particular, and they are not instantiable. Again, it seems intuitively obvious that this should apply to paintings. A painting just seems to be a particular individual object. Because paintings are concrete, it seems very difficult to see how they could plausibly be identified with types or universals, or indeed anything that admits of instantiation. The Mona Lisa is not instantiated by the physical object hanging in a gallery: it is that object. However, it has commonly thought that repeatable works of art (fictions, works of music, and so forth) must be types, in order to account for their repeatability. The relationship between a novel and any particular copy of that novel is thought to be a type/token relation, or a universal/particular relation. To the artefactualist this is not so. A work of music or indeed a fictional character is a particular entity as much as a painting is, though an abstract one. Works of art have properties that types cannot have. The

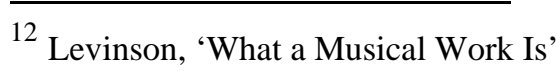


most important of these is modal flexibility: a fiction or a work of music could have been different in various ways. An author could have written the very same novel, but with different words, and a composer could have composed the very same work, but with different notes. As Guy Rohrbaugh notes, 'a substantial fragment of critical talk presumes the meaningfulness of sentences like, ‘Picasso’s Les Demoiselles d’Avignon would have been better had it lacked certain stylistic inconsistencies', which, on its face, concerns a certain possibility for this very painting. ${ }^{13}$ We can make analogous remarks about works of music, such as ‘Bruckner’s Ninth Symphony might have been finished had he lived longer'. ${ }^{14}$ Rohrbaugh also claims that works of art are temporally flexible, or can change over time. ${ }^{15}$ For instance, the paint on a painting can fade, or the negative of a photograph can be damaged. However, it is much more difficult to see how novels and symphonies can be held to change over time, at least in terms of the properties relevant to their appreciation. Even if they cannot, the modal flexibility of works of art does enough work to show that works of art cannot be identical to types. If works of art are modally flexible in this way, we require a means for individuating these objects quite different from that used for individuating types. Type theorists individuate works of art solely by the conditions that any individual object must meet in order to be a token of the type. In other words, the only thing that can be taken into account on a type theory is the form or structure of the work of art. The artefactualist does not individuate on the basis of structure, but on the basis of the historical circumstances of the

\footnotetext{
${ }^{13}$ Rohrbaugh, 'Artworks as Historical Individuals', European Journal of Philosophy, vol. 11, no. 2, August 2003, p. 183

${ }^{14}$ ibid., p. 182

${ }^{15}$ ibid., p. 186
} 
work's creation. This is in fact a highly intuitive way to individuate works, and the inability of type theories to do this should be seen as a mark against them.

Other philosophers have argued for an artefactual theory, but few if any have sought to draw extended analogies between fictional characters and the different arts to illuminate the theory. The most prominent defender of the view is Amie Thomasson. ${ }^{16}$ She focuses particularly on the case of fictional characters, which is a reason for the focus put on them in this thesis. However, she also believes that artefactualism is the correct view for all of the ontology of art, ${ }^{17}$ and arguments strikingly similar to those given for (and against) Thomasson's view of fictional characters appear in the literature on the ontology of music. Rohrbaugh ${ }^{18}$ defends a similar view to Thomasson's, which he takes to be applicable to all repeatable works of art. This thesis will develop the account of artefactualism about art in more detail than Thomasson and Rohrbaugh. Treating fictional characters as importantly analogous to works of art will enable clear connections to be drawn between the literatures on the metaphysics of the objects in these different domains.

Both Thomasson and Rohrbaugh argue that when doing ontology of art we should take careful consideration of the ordinary practices of both the general public and of critics. ${ }^{19}$ According to these practices, works of art are created individual entities, so philosophical theories have a prima facie reason to treat

\footnotetext{
${ }^{16}$ Thomasson, Fiction and Metaphysics

${ }^{17}$ ibid,, pp. 129-130; Amie L. Thomasson, 'The Ontology of Art' in Peter Kivy (ed), The Blackwell Guide to Aesthetics (Malden: Blackwell Publishing, 2004), pp. 88-90

${ }^{18}$ Rohrbaugh, 'Artworks as Historical Individuals'

${ }^{19}$ See Amie L. Thomasson, 'Fictional Characters and Literary Practices', British Journal of Aesthetics, vol. 43, no. 2, April 2003, especially pp. 143-147, and Rohrbaugh, 'Artworks as Historical Individuals', pp. 178-179
} 
them as such too. Artefactualists reject revisionary ontologies of art. They claim that our artistic practices are the best evidence that we have about the metaphysics of art works, because to say otherwise would be to say that our ordinary interpretive practices are radically false. It is extremely unlikely that this should be so. Theorising about the ontology of art should meet David Davies' 'pragmatic constraint': 'Artworks must be entities that can bear the sorts of properties rightly ascribed to what are termed 'works' in our reflective critical and appreciative practice; that are individuated in the way such 'works' are or would be individuated, and that have the modal properties that are reasonably ascribed to 'works', in that practice. ${ }^{20}$ The ontology of art should be beholden to our critical practices concerning art, and artefactualism is the theory that best coheres with these.

The thesis will proceed by motivating and defending artefactualism in the domains mentioned above. There are differences of detail between the cases. Our intuitions regarding fictional characters are rather different from our intuitions regarding works of music. Most obviously, we are often willing to deny that a fictional character exists, but are not willing to say so of a symphony or a work of fiction. It also seems that fictional characters do not properly count as works of art. For instance, on Levinson’s intentional-historical definition of art, a work of art is something which is or was intended to be regarded in the same way as some prior work of art was intended to be regarded. ${ }^{21}$ It is at least not obvious that fictional characters have historically been regarded as works of art, and thus

\footnotetext{
${ }^{20}$ David Davies, Art as Performance (Malden, MA: Blackwell, 2004), p. 18. See also David Davies, 'The Primacy of Practice in the Ontology of Art', The Journal of Aesthetics and Art Criticism, vol. 67, no. 2, Spring 2009, pp. 159-165

${ }^{21}$ Jerrold Levinson, 'The Irreducible Historicality of the Concept of Art', British Journal of Aesthetics, vol. 42, no. 4, Oct. 2002, p. 367
} 
that they should be regarded as works of art now. However, there are important similarities between fictional characters and works of art. It is frequently observed in the literature that fictional characters and other things like works of fiction fit into the same ontological category. ${ }^{22}$ Van Inwagen writes that creatures of fiction (among which are included fictional characters) are part of a 'broader category of things I shall call theoretical entities of literary criticism, a category that also includes plots, sub-plots, novels (as opposed to tangible copies of novels), poems, meters, rhyme schemes, borrowings, influences, digressions, episodes, recurrent patterns of imagery, and literary forms ("the novel," "the sonnet"). ${ }^{23}$ Of these, at least novels and poems can be properly considered to be works of art. Moreover, fictional characters, while not necessarily works of art in themselves, do seem to be an artistic achievement on the author's part (particularly complex characters like Hamlet or Anna Karenina). The existence of such significant parallels between fictional characters and other works of art does suggest that there are relevant similarities between the two cases. Given both this and the extensive literature on the metaphysical status of fictional characters, and this literature's similarity to other discussions in the ontology of art, the use of fictional characters as a case study in chapter two is justified. The differences in detail between the cases of fictional characters on the one hand and works of music and works of fiction on the other hand do not take away from the important similarities between the cases. All are artefacts, and all have the relevant properties to make them artefacts.

\footnotetext{
${ }^{22}$ For instance Thomasson, Fiction and Metaphysics, pp. 139-143

${ }^{23}$ van Inwagen, 'Creatures of Fiction', pp. 302-303
} 
The second chapter of this thesis will discuss fictional characters. The third will discuss works of music. The fourth will discuss works of fiction. Each chapter will have three sections, to argue for the claims that these objects are existent, and created, and individuals. 


\section{Fictional Characters}

\subsection{Existence}

Fictional characters, such as Sherlock Holmes, exist. They are parts of the actual world. This is a seemingly counter-intuitive claim. It might be thought that saying that something is a fictional character is simply saying that it does not exist (at least, someone who accepts the truth of 'Sherlock Holmes is a fictional character' will frequently be prepared to deny the truth of 'Sherlock Holmes exists').

In discussing this issue it will be useful to distinguish between different kinds of statements that can be made about fictional characters. ${ }^{24}$ First, there are statements about the content of a fiction, such as

(1) Sherlock Holmes is a detective.

These can be known as fictional statements, and are true (if they are true) by virtue of the content of a fiction. For a fictional statement to be true, it seems as if fictional characters must exist. For instance, (1) seems to say, of Sherlock Holmes, that he is a detective, and this can only be so if Sherlock Holmes exists. However, there is an easy way to paraphrase fictional statements so as to avoid any commitment to fictional characters. This is to treat them as implicitly prefixed by 'According to the (relevant) story ...'. Thus, (1) is a shorthand way of saying

\footnotetext{
${ }^{24}$ Brock, 'Fictionalism about Fictional Characters', pp. 4-5
} 
(2) According to the Conan Doyle stories, Sherlock Holmes is a detective.

This does not (at least, not clearly) create any ontological commitment to Sherlock Holmes, and thus provides a way for anti-realists ${ }^{25}$ to deal with the apparent truth of fictional statements. However, there are other statements about fictional characters that are not so easily dealt with:

(3) Sherlock Holmes is a fictional character.

(4) Holmes is admired by many members of the British Police Force. ${ }^{26}$

(5) Holmes symbolizes mankind's ceaseless striving for truth. ${ }^{27}$

These are critical statements. They cannot be paraphrased in the same way as fictional statements, because they are not statements that are true according to the story. For instance, if the ‘According to the story’ prefix was added to (3), we would get

(3a) According to the Conan Doyle stories, Sherlock Holmes is a fictional character.

(3a) is clearly false. According to the stories, Sherlock Holmes is not a fictional character but a human being. In fact, it is clear that in making a statement like (3) we are stepping outside of the story, as it were, to talk about Sherlock Holmes from a real-world perspective.

\footnotetext{
${ }^{25}$ And artefactualists, as it happens.

${ }^{26}$ Brock and Mares, Realism and Anti-Realism, p. 201

${ }^{27}$ David Lewis, 'Truth in Fiction', American Philosophical Quarterly, vol. 15, no. 1, January 1978, p. 38
} 
Peter van Inwagen argues that the practices of literary criticism provide us with a reason to postulate fictional objects. In particular, he believes that we can make legitimate inferences from sentences that ostensibly quantify over fictional characters. From the statement 'There is a fictional character who, for every novel, either appears in that novel or is a model for a character who does.' we can correctly infer that 'If no character appears in every novel, then some character is modelled on another character. ${ }^{28}$ Though the first of these sentences is presumably false, the logical structure of the inference is still correct, and the translation of the sentences into quantifier-variable idiom allows the further inference that there is a fictional character. A sentence that is true which allows for a similar inference is: 'In some novels, there are important characters who are not introduced by the author till more than halfway through the work' ${ }^{29}$ Van Inwagen makes two claims about possible paraphrases of such sentences. The first is that it is difficult to see how many of the more plausible paraphrases can succeed in allowing us to account for the logical consequences of the original sentences. ${ }^{30}$ The second is a concern about systematicity: 'such paraphrases would be long and messy if they could be got at all; and maybe they couldn't be got ... So why embark on such an enterprise?' ${ }^{31}$ Postulating fictional characters provides a smoother and more uniform way of making sense of critical discussions of fiction.

\footnotetext{
${ }^{28}$ Peter van Inwagen, ‘Existence, Ontological Commitment, and Fictional Entities’ in Michael J. Loux and Dean W Zimmerman (eds), The Oxford Handbook of Metaphysics (Oxford; New York: Oxford University Press, 2003), p. 136

${ }^{29}$ ibid., p. 138

${ }^{30}$ van Inwagen, ‘Creatures of Fiction', pp. 303-304

${ }^{31}$ ibid., p. 304
} 
Takashi Yagisawa ${ }^{32}$ has argued against van Inwagen. He claims that van Inwagen's argument for the existence of fictional characters relies on taking the claims of literary criticism at face value, and that it is illegitimate to do so. His first gloss on van Inwagen's argument is as follows:
(A) It is a truth of literary criticism that $\Phi$.
(B) That $\Phi$ implies that $\alpha$ exists
(C) $\quad \alpha$ exists. $^{33}$

So,

This argument, as Yagisawa notes, is clearly invalid. However, it is not what van Inwagen had in mind, because he urges that the sentences of literary criticism be taken at face value. Instead of (A), therefore, van Inwagen would best be read as meaning

(A') (It is true that) $\Phi .{ }^{34}$

(C) follows from $\left(\mathrm{A}^{\prime}\right)$ and $(\mathrm{B})$, and Yagisawa calls this 'the strongest reconstruction of van Inwagen's argument [he] can think of that is faithful to his text ${ }^{35}$ He then objects to $\left(\mathrm{A}^{\prime}\right)$, on the basis that literary criticism should not be taken at face value. Yagisawa claims that van Inwagen’s argument rests on a false assumption: that literary criticism aims at discovering truths about the world. ${ }^{36}$ Instead, Yagisawa argues that literary criticism 'is not a discipline or

\footnotetext{
${ }^{32}$ Takashi Yagisawa, ‘Against Creationism in Fiction’, Philosophical Perspectives, vol. 15, 2001, pp. 160-167 ${ }^{33}$ ibid., p. 163

34 ibid.

35 ibid.

${ }^{36}$ ibid.
} 
activity aimed at propositional truth at all. Instead it is an activity aimed at practical results', namely, helping us to appreciate literary works. ${ }^{37}$ Because of this, he argues that we have no reason to treat any sentences indigenous to literary criticism as literally true, and thus have no reason to suppose that the entities that they apparently quantify over exist. However, as Jeffrey Goodman has argued, these facts about literary criticism do not imply the conclusion that Yagisawa draws. Even if literary criticism is not as useful for finding out about the world as, say, physics, and even if the primary purpose of literary criticism is not to assert truths, it can still be the case that some critical statements about fictional characters are literally true. ${ }^{38}$ This also points to how Yagisawa’s reconstruction of van Inwagen's argument is inaccurate. Yagisawa claims that van Inwagen is committed to the view that all of the sentences of literary criticism are true, and thus thinks that all that is required to reject van Inwagen's view is to show that some of them are not. However, van Inwagen is not committed to this. All that is required for van Inwagen's argument for the existence of fictional characters to succeed is that some of the sentences of literary criticism are literally true. Sentences like (3) seem to be good examples of these. Any sentence that describes the properties that a fictional character has, as opposed to the properties they are ascribed in the story, will succeed in providing van Inwagen with an appropriate example. ${ }^{39}$ As there are such sentences, and many of them are true, Yagisawa's response to van Inwagen does not succeed.

\footnotetext{
${ }^{37}$ ibid., p. 164

${ }^{38}$ Jeffrey Goodman, 'A Defense of Creationism in Fiction', Grazer Philosophische Studien, vol. 67, 2004, pp. 140-141

39 ibid., pp. 136-137
} 
However, there is another set of statements which are part of our pretheoretical beliefs about fictional characters, which might be called singular non-existence statements:

(6) Sherlock Holmes does not exist.

This statement cannot be held by the artefactualist to be true. If there are fictional characters, then fictional characters exist. (6) cannot, however, be paraphrased away by prefixing 'According to the fiction'. Another analysis of the sentence is required. The most frequent way for realists about fictional characters to deal with sentences like (6) is to claim that there is an implicit restriction on quantification. ${ }^{40}$ Implicit restrictions on quantification are not uncommon in ordinary speech. In David Lewis' example, we can look in the fridge and say that there is no beer without thereby denying that there is beer outside the fridge. ${ }^{41}$ In the case of Sherlock Holmes, we are restricting our quantification to the domain of real people, which the artefactualist accepts does not contain Sherlock Holmes. The most plausible paraphrase of (6) is thus

(6a) There is no such person as Sherlock Holmes.

This is, according to the artefactualist, true, because Sherlock Holmes is not a person, but a fictional character. Of course, not all fictional characters are people, but the analysis can easily be modified to account for this (for instance, 'There is no such concrete object as fictional character $x$. ', or, 'There is no such causally efficacious object as fictional character $x$.', or, 'There is no object that has all of the properties that fictional character $x$ holds.') Kendall Walton has objected that

\footnotetext{
40 Thomasson, Fiction and Metaphysics, p. 112

${ }^{41}$ Lewis, On the Plurality of Worlds, pp. 136-137
} 
sentences of the form ' $x$ does not exist' do not seem to permit of any ambiguity in the way that realists about fictional characters argue that (6) does. ${ }^{42}$ Statements of the form 'There is no $x$ ' may permit of an implicit restriction on quantification, but Walton claims that non-existence statements do not. He suggests that 'the use of “exists” prevents the quantification from having a contextually determined domain restriction', and thus that the realist account of (6) fails to capture the sentence's meaning. ${ }^{43}$ Anyone who believes that there is a difference between being and existence will not find this such a problem, but the artefactualist claims that everything that is exists. The response that this kind of realist has to make, then, is simply to reaffirm (6a) and analogous paraphrases as the appropriate way of understanding non-existence statements regarding fictional characters. A further point to note is that even if Walton is correct, there is still the problem (for realist and anti-realist views) of making sense of any negative existential statement. The artefactual theory is thus not significantly worse off in this regard.

Anti-realists about fictional characters can take singular non-existence sentences about fictional characters as straightforwardly true. However, they must paraphrase away both fictional and critical claims. The most popular variety of anti-realism about fictional characters which attempts to do this is the pretense theory put forward by Kendall Walton. ${ }^{44}$ Pretense theory is a form of fictionalism, according to which sentences purporting to refer to fictional characters do not express propositions at all, but can be used to assert real-world

\footnotetext{
${ }^{42}$ Kendall L. Walton, 'Restricted Quantification, Negative Existentials, and Fiction', Dialectica, vol. 57, no. 2, 2003, pp. 239-242

${ }^{43}$ ibid., p. 241

${ }^{44}$ Kendall Walton, Mimesis as Make-Believe
} 
truths. ${ }^{45}$ Walton's theory of the metaphysics of fiction comes from his overall theory of how fiction works. He claims that make-believe is the key notion. Other theories of fiction frequently begin by noting that we often make apparently true statements which refer to fictional characters. ${ }^{46}$ Walton thinks that this is mistaken, and we should start with the acts of pretense, or the games of make-believe that we participate in when we read works of fiction. ${ }^{47} \mathrm{~A}$ work of fiction is a prop in a game of make-believe, that is, an object which constrains the make-believe and makes some pretenses appropriate. ${ }^{48}$ Sentences that ostensibly feature the names of fictional characters can be paraphrased into sentences that describe the content of a game of make-believe. However, these paraphrases need not capture the meanings of the original sentences, but only what is being asserted in the utterance of the sentences. ${ }^{49}$ This move also allows Walton to avoid the systematicity requirement for paraphrases suggested by Peter van Inwagen. Walton claims that it would be question-begging to suppose that what people assert in uttering a sentence purporting to refer to a fictional character has the logical structure of the sentence itself, so paraphrases should not be obliged to display this logical form. ${ }^{50}$ It is easy to understand how assertions about the content of a fiction could be understood as make-believe. When we say 'Sherlock Holmes is a detective', Walton claims that we are not making an assertion, but are pretending to make an assertion. Statements that are made as part of a pretense can give information about the real world, however. The statement 'Sherlock Holmes is a detective' can be paraphrased in a way that

\footnotetext{
${ }^{45}$ ibid., p. 396

${ }^{46}$ ibid., p. 391

${ }^{47}$ ibid.

48 ibid. pp. 37-38

${ }^{49}$ ibid., p. 417

${ }^{50}$ ibid., pp. 417-419
} 
shows what this information is. The paraphrase would be something like: 'The Conan Doyle stories are such that one who engages in pretense of kind $\mathrm{K}$ (that is, pretense that Sherlock Holmes is a detective) in a game authorised for them makes it fictional of himself in that game that he speaks truly'. ${ }^{51}$ This is an untidy paraphrase of a seemingly simple sentence, but it is able to be systematised, and the claim that fictional assertions involve pretense is intuitively plausible. However, it is not so obvious that 'Sherlock Holmes is a fictional character' is part of a systematic pretense. To support his theory, Walton has to claim that 'Sherlock Holmes is a fictional character' is true as part of a 'more or less ad hoc or unofficial' game of make-believe, in which there are two kinds of people, namely real people and fictional characters. ${ }^{52}$ In such a game, to say 'Sherlock Holmes is a fictional character' is fictionally to speak truly. This is an awkward way to make sense of a seemingly true statement. It is highly doubtful that we are ever pretending that there are different kinds of people in our critical discussions of fiction. Walton's suggestion that the claim that Sherlock Holmes is a fictional character is part of a pretense also requires that it be possible for someone to be engaged in pretense without knowing that they are. ${ }^{53}$ That the pretense theory is committed to a thesis that implies a failure of first-person authority over one's own mental states ${ }^{54}$ is an uncomfortable conclusion.

Another variety of anti-realism is the prefix fictionalism about fictional characters defended by Stuart Brock. ${ }^{55}$ Brock wants to meet van Inwagen’s challenge to provide a systematic paraphrase of our claims about fiction. Like the

\footnotetext{
${ }^{51}$ ibid., p. 400

${ }^{52}$ ibid., p. 423

${ }^{53}$ Jason Stanley, 'Hermeneutic Fictionalism', Midwest Studies in Philosophy, vol. 25, 2001, p. 46

${ }^{54}$ ibid., p. 47

${ }^{55}$ Brock, 'Fictionalism about Fictional Characters'
} 
artefactualist, he paraphrases fictional statements by adding the prefix 'According to the fiction'. ${ }^{56}$ Unlike realists, he treats singular non-existence statements about fictional characters as straightforwardly true. He puts forward a novel treatment of critical statements, however. His proposal is 'parasitic' on the realist's account of critical statements. ${ }^{57}$ The realist takes critical statements as straightforwardly true, but Brock argues that they can be paraphrased by adding the prefix 'According to the realist's hypothesis'. ${ }^{58}$ This is a way of allowing us to continue having our critical talk about fictional characters without incurring any ontological commitment to them. Though the fictionalist view does not imply that realism about fictional characters is false, it is reasonable to treat it as an anti-realism (or at least a live option for the anti-realist). An objection to this view comes from Walton. ${ }^{59}$ He argues that the fictionalist cannot provide an adequate and meaning-preserving paraphrase of critical claims. This is because the meaning of a declarative sentence, such as the fictionalist's paraphrase of a critical claim, is generally taken to be determined compositionally. For a sentence to have a meaning, then, every part of it must have a meaning. However, according to Millianism, the meaning of a name is its referent. Because most fictionalists will believe that fictional names do not have referents, their paraphrases of critical claims cannot preserve the meanings of these claims. The prefix fictionalist has a number of options open to respond to this. They can deny that the meaning of a sentence is determined compositionally, or deny Millianism, or deny that a term with no referent makes a sentence meaningless. ${ }^{60}$ Perhaps a more serious problem for the prefix fictionalist is that they have given us no

\footnotetext{
${ }^{56}$ ibid., p. 5

${ }^{57}$ ibid., p. 9

58 ibid.

${ }^{59}$ Walton, Mimesis as Make-Believe, p. 391ff

${ }^{60}$ Brock and Mares, Realism and Anti-Realism, p. 217
} 
reason to think that our ordinary critical claims about fictional characters are elliptical for their paraphrases. It is implausible to think that when we utter (3) (Sherlock Holmes is a fictional character), we are in fact best understood as making a claim about a particular philosophical theory about the ontological status of fictional characters. Until the fictionalist can find a reason not to take (3) at face value, they have not given a persuasive argument that their paraphrases are necessary.

\subsection{Creation}

Among realists about fictional characters, fictional characters are generally thought to be abstract objects. There is clearly no concrete actual person who corresponds to Conan Doyle’s descriptions of Sherlock Holmes, and Kripke has given an argument that shows that even if there were, this person would not be Sherlock Holmes. Kripke writes that '[s]everal distinct possible people, and even actual ones such as Darwin or Jack the Ripper, might have performed the exploits of Holmes, but there is none of whom we can say he would have been Holmes had he performed these exploits. For if so, which one? ${ }^{61}$ There seem to be a vast number of possible people who have all of the properties that Sherlock Holmes is ascribed in the stories, and it is entirely arbitrary to choose one of them as 'the' Sherlock Holmes instead of any other. It cannot be the case, either, that all of them are Sherlock Holmes. We have the intuition that Darwin and Jack the Ripper are different people, and would continue to be so regardless of how similar they each became to Holmes. The problem of providing secure identity

\footnotetext{
${ }^{61}$ Saul Kripke, Naming and Necessity (Oxford: Blackwell, 1980), p. 158
} 
conditions is thus a reason to think that fictional characters cannot be concrete objects. Another reason to think this is that concrete objects have spatiotemporal locations, and abstracta do not. Fictional characters do not seem to have spatiotemporal locations. They are not located at the places ascribed to them in their books: there was not a 221B Baker Street at the time in which the Holmes stories were set. Meinongians such as Terence Parsons will deny this. ${ }^{62}$ Parsons claims that fictional characters are concrete objects which are located exactly where stories about them say that they are. ${ }^{63}$ The reason that we cannot find Sherlock Holmes in London is that Sherlock Holmes does not exist. This view is implausible not only because it relies on a distinction between being and existence, but because it implies that two distinct objects can occupy the same spatiotemporal region. Fictional characters are also not located wherever stories about them are located. Works of fiction are themselves abstract objects, and thus have no spatiotemporal locations. ${ }^{64}$ Token copies of a story contain token descriptions of fictional characters, but the existence of a concrete description of an entity in a particular place does not imply that the entity is at that place as well. ${ }^{65}$ For instance, a token description of a real person in a work of non-fiction does not imply that the person is located where the description is (and no-one would take it to do so). There are no other plausible options for a concrete realist to use to tell us where fictional characters are. ${ }^{66}$ If there are fictional characters, then, they are abstract.

\footnotetext{
62 Terence Parsons, Nonexistent Objects (New Haven and London: Yale University Press, 1980), pp. 49-60

63 ibid., p. 55

${ }^{64}$ See chapter four for further discussion of this.

65 Thomasson, Fiction and Metaphysics, p. 37

${ }^{66}$ Though Jeffrey Goodman, an abstract realist about fictional characters, thinks they do have a spatial location: roughly, Earth. See Jeffrey Goodman, 'Where is Sherlock Holmes?', Southern Journal of Philosophy, vol. 41, 2003, pp. 183-198.
} 
Philosophers have frequently believed that abstract objects cannot have any causal connection with us. Because of this, creationism about fictional characters has been seen as an unintuitive view. There are, however, good reasons to accept it. One of these is that we accept the truth of sentences such as (7) Sherlock Holmes was created by Arthur Conan Doyle.

As Amie Thomasson notes, our acceptance of the created status of fictional characters can help us make sense of some of our modal claims about fiction. For instance, 'we count our good luck that certain characters like Sherlock Holmes were created when, given a busier medical practice, Arthur Conan Doyle might never have created him ${ }^{67}$ It does not make sense to do this if Holmes is not literally created. An even clearer example that Thomasson uses is this: 'If someone contended that George Washington was a great fan of Sherlock Holmes, we might object that in Washington's time there was no Sherlock Holmes - the Holmes character was not created until $1887,{ }^{68}$ Certainly no-one, whether a creationist about fictional characters or not, would accept the truth of 'George Washington was a great fan of Sherlock Holmes’. However, the creationist can show why it is literally impossible for this to be the case: Holmes cannot be admired until after he is created. A non-creationist realist will have to accept that it is logically possible, though fantastically unlikely, that Washington was, in fact, a fan of Holmes. This is an unacceptable consequence.

\footnotetext{
${ }^{67}$ Thomasson, Fiction and Metaphysics, p. 6

68 ibid., pp. 5-6
} 
There is a further reason for treating fictional characters as created. Anyone who wants to claim that fictional characters exist requires a way to provide identity conditions for them, and creationism about fiction enables this to be done. Simply, a fictional character has the essential property of being created in the very act of creation in which it was. Two characters which appear in different stories are identical if and only if they were both created in the same act of creation, or are appropriately causally connected (through a causal chain of the kind described by Kripke) ${ }^{69}$ to the original act of creation. Thomasson calls the dependence of a fictional character on the circumstances of its creation a 'rigid historical dependence'. Fictional characters are also dependent on human intentionality for their continued existence. A fictional character can go out of existence if no records or memories of it survive. Fictional objects thus have a 'generic constant dependence' on concrete copies of the fictions in which they appear, and on there being competent users of the language who are capable of reading these fictions. ${ }^{70}$ They are generically dependent because they depend on there being some concrete copy and some reader, but not on any particular copy or any particular reader. They are constantly dependent because they exist only as long as there is some copy and some reader. ${ }^{71}$ It is worth noting at this point that Thomasson's theory fits fictions into her ontology in the same category as fictional characters, that is, as dependent abstract objects. Because of this, Thomasson's ontology is not qualitatively unparsimonious. ${ }^{72}$ If we already believe in the existence of fictions, then a belief in the existence of fictional characters is not a belief in a different kind of entity.

\footnotetext{
${ }^{69}$ Kripke, Naming and Necessity

${ }^{70}$ Thomasson, Fiction and Metaphysics, p. 36

71 ibid.

${ }^{72}$ See David Lewis, Counterfactuals (Cambridge: Harvard University Press, 1973), p. 87, on qualitative and quantitative parsimony
} 
In Thomasson's theory, the appearance of a character in a particular fiction is a result of a deliberate and knowing act by a particular author. This is the basis of her conditions for identifying characters across fictions. The first condition she suggests is as follows:

We can at least specify an important necessary condition C for the identity of characters $\mathrm{x}$ and $\mathrm{y}$ appearing in literary works $\mathrm{K}$ and $\mathrm{L}$ respectively: The author of $\mathrm{L}$ must be competently acquainted with $\mathrm{x}$ of $\mathrm{K}$ and intend to import $\mathrm{x}$ into $\mathrm{L}$ as $\mathrm{y} .$. By "competent acquaintance” $\mathrm{I}$ mean the kind of acquaintance that would enable the author to be a competent user of the name of $\mathrm{x}$ (supposing $\mathrm{x}$ were named), as it is used in $\mathrm{K}^{73}$

It can clearly be seen that this condition can closely be linked with the causal chain theory of reference developed by Kripke. ${ }^{74}$ For an author to be referring to a particular (and previously created) fictional character, they must have learnt the name from an appropriate causal chain in an appropriate way (for instance, by reading the book that the character first appeared in). This seems to be a sensible necessary condition for trans-fictional identity. It allows characters in literary works in the same series be identified as the same, because (for instance) Arthur Conan Doyle was competently acquainted with the Sherlock Holmes of A Study in Scarlet, as he was the author of the work, and he intended to import Sherlock Holmes into The Sign of the Four. It also solves a case that Thomasson discusses - the case of Pamela. ${ }^{75}$ Pamela appears in Samuel Richardson's Pamela, and this book is parodied by Henry Fielding’s Joseph Andrews. Thomasson also imagines a Fred Jones, who by sheer coincidence and without any knowledge produces a

\footnotetext{
73 ibid., p. 67

${ }^{74}$ Kripke, Naming and Necessity

75 Thomasson, Fiction and Metaphysics, p. 56
} 
fiction word-for-word identical to Richardson’s. Intuitively, the Pamelas of Richardson's and Fielding's works are the same, but the Pamela of Jones's work is a different (though remarkably similar) character. The condition for identity above can make this case fit this intuition. Fielding is competently acquainted with the Pamela of Richardson's work, and intends to import her into his own work, and Jones does not. Another way to put this is that the two characters originate in different acts of creation. Fielding is competently acquainted with the original act of creation (through having read the relevant book), and Jones is not. There is a causal chain leading from Richardson's act to Fielding's, and there is not one leading from Richardson’s act to Jones’s. If we accept a Kripkean view of reference, then we find that creationism about fictional characters allows us to present a viable way of identifying characters across stories. This is a major argument in favour of the creationist view.

Creationism about fictional characters is denied by both anti-realists and Platonists. Anti-realists may say that creationism is trivially true, in that all the fictional characters there are (none of them) are created, but can also say that it is false to say that Sherlock Holmes was created, because ' $x$ was created' implies ' $x$ exists'.

The reason that Platonists about fictional characters do not believe that fictional characters can be created is that abstract objects cannot have causal connections with us. (This point also applies to David Lewis’ concrete realism.) To create an abstract object on a Platonist account is to bring into existence something with which you can have no causal connection, which is a patent absurdity. An 
abstractum which is necessarily existing in logical space cannot be brought into being by any intentional action. Harry Deutsch described the conflict between creationism and the ordinary view of abstract objects as the 'creation problem'. The creation problem can be best represented as an argument as follows:

1. Fictional characters are abstract objects.

2. Creating an object entails bringing it into existence or causing it to exist.

3. Abstract objects cannot stand in causal relations.

4. Therefore, fictional characters are not created. ${ }^{76}$

Deutsch's solution to the creation problem is a novel one. It is generally thought that the creation of any object implies that object's being brought into existence. Indeed, this may be regarded as a fact about the concept of creation. ${ }^{77}$ Deutsch rejects this. He argues for this by noting that there is a plenitude of abstract objects, and therefore any description that an author makes of a character is almost certain to describe some abstract object (Deutsch does not make it clear whether the line is drawn at impossibility or at some other point). The other important aspect of the creation of fictions on Deutsch's account is that the author's word is law. It is impossible for an author to misdescribe a character he is authoring. The author's activity is stipulative. Deutsch calls this the 'principle of poetic license'. ${ }^{78}$ These two points taken together are supposed to show that literary creation is stipulation: an author creates a character by stipulating what the character is like. This is creation because of the principle of poetic license the author's stipulation cannot be wrong, and is attributive of the character. This

\footnotetext{
${ }^{76}$ Deutsch, 'The Creation Problem', p. 210

${ }^{77}$ Yagisawa, 'Against Creationism in Fiction', p. 156

${ }^{78}$ Deutsch, 'The Creation Problem’, p. 211
} 
is a looser sense of create than we are used to using. Deutsch in fact suggests that 'create' in a literary context means something more like 'invent in the imagination' than 'bring into existence'. ${ }^{79}$ Because of this, Deutsch’s creationism is quite different from the creationism of the artefactualist. It could be argued that Deutsch is not a creationist about fictional characters at all, but this may be slightly misleading, as he does believe that fictional characters are created. He is not attempting to propose a 'watered-down' sense of creation, but a different one. It can be argued, though, that Deutsch's version of creation as stipulative selection is not any kind of creation at all. Stefano Predelli notes that '[a]ny freely chosen consistent collection of arithmetical properties, for that matter, may be guaranteed to correspond to a class of numbers, without it being appropriate to credit the selector with the power of having created that set-theoretic item' ${ }^{80}$ Deutsch's solution to the creation problem strays so far from our ordinary notion of creation that it will be better to find another solution.

Ontological realists about fictional characters, that is, those who believe that there are fictional characters, typically do not base their judgement on the truth of statements about the content of a fiction. The statements that do cause the realist to commit to fictional statements are the statements that are made in our critical discussion of fiction. Perhaps the paradigmatic example of such a statement is:

(3) Sherlock Holmes is a fictional character.

Any theory of fiction is absolutely obliged to be able to make sense of this statement. The statement seems to imply that an individual (Sherlock Holmes) is

\footnotetext{
79 ibid., p. 216

${ }^{80}$ Stefano Predelli, 'Musical Ontology and the Argument from Creation', British Journal of Aesthetics, vol. 41, no. 3, July 2001, p. 287
} 
an example of a particular kind of thing (a fictional character). To make sense of the statement requires some kind of notion of what this kind of thing is, and what other objects both do and (importantly) do no belong to it. Eternalist (noncreationist) views of fiction must be able to delineate what are and what are not fictional characters in order to make sense of (3). It will be argued that they cannot do this.

On the possibilist view (the view of David Lewis), Sherlock Holmes is a human being, the same kind of thing as you and me. The difference between Sherlock Holmes and you and me is that we are actual and he is not, which simply means that we are human beings in this world and he is a human being in another world. I am certain that I am not a fictional character, so if Sherlock Holmes is the same kind of thing as me, but differs only in virtue of his non-actuality, then he is not a fictional character either. Another thing of the same kind as Sherlock Holmes is Frederick Holmes, who is the unactualised possible human being named 'Frederick Holmes' who does exactly the same things as Sherlock Holmes does. There should be some basis on which Sherlock Holmes is a fictional character, but I am not, and Frederick Holmes is not. The difference seems to be that in the actual world there are fictional stories, authored by Sir Arthur Conan Doyle, about Sherlock Holmes, but there are no fictional stories about me (I am actual, after all) or about Frederick Holmes. However, this creates a further question. On what basis can the actual Conan Doyle stories be said to be about the non-actual person Sherlock Holmes? It cannot be because Sherlock Holmes is the only nonactual person to have done what Doyle reports him as doing, because Frederick Holmes did those things too. In fact, there could be actual people, such as 
Darwin or Jack the Ripper, who performed the deeds of Holmes in another possible world (at least, if we believe in trans-world identity). If Conan Doyle was just describing the adventures of some non-actual detective, he could have been mistaken about the details. It would be possible that the Sherlock Holmes stories are in fact about Frederick Holmes, and thus that Frederick Holmes is a fictional character and Sherlock Holmes is not. That is an unacceptable consequence. It also cannot be the case that every person who performs the acts that Sherlock Holmes is ascribed the performance of in the stories is Sherlock Holmes, because Darwin and Jack the Ripper would still be different people, no matter how similar they each became to Holmes. ${ }^{81}$ Even if we take Sherlock Holmes to be anyone who performs the acts ascribed to Sherlock Holmes, and recorded as doing so by Watson, and called 'Sherlock Holmes', we clearly do not have a unique individual who is Sherlock Holmes. There are (at least on Lewis’ account) many possible individuals who fit.

There is in fact an even more serious problem with the claim that Sherlock Holmes is a fictional character because of the actual Conan Doyle stories about him. It is simply that the Conan Doyle stories are not about him. The possible worlds of David Lewis are totally causally unconnected to us, and the people in them are also totally causally unconnected to us. In order for the actual Conan Doyle stories to be about the non-actual person Sherlock Holmes, there would have to be some causal connection between the two, or there must be some way for Conan Doyle to pick out Sherlock Holmes without some causal connection. As regards the first option, the Conan Doyle stories actually exist, and would

\footnotetext{
${ }^{81}$ Kripke, Naming and Necessity, p. 158
} 
actually exist even if Sherlock Holmes did not exist in any possible world. Sherlock Holmes exists, but is not actual, and would have existed even if there were no actual stories with a character named 'Sherlock Holmes'. The person Sherlock Holmes and the Conan Doyle stories are totally independent of one another. ${ }^{82}$ For the second option, Conan Doyle cannot succeed in referring by description to Sherlock Holmes. This is because Sherlock Holmes is not a unique individual. The best that Conan Doyle can do is to refer to a set of individuals in different possible worlds (who are presumably counterparts of each other). If we are to take the Conan Doyle stories as referring to one Holmes, there is no principled way to decide which one. We cannot thus say of any non-actual Holmes that Conan Doyle was referring to him and not to somebody else. It therefore cannot be said that Sherlock Holmes is a fictional character because of (or in virtue of) the Conan Doyle stories. Individuating fictional characters from unactualised possibles must thus be done in some other way, and there are no other obvious plausible candidates.

Now to briefly describe how I believe the argument generalises to all eternalist views. The basis of the view of eternalism about fictional characters is that fictional characters are not the kind of thing that can be created because they are not the kind of thing that authors can have the right kind of causal interaction with. If authors cannot create characters, though, on what basis can they be said to be writing about a particular character? Unless the character has some real causal properties (of which the most useful would be 'created by such-and-such

\footnotetext{
${ }^{82}$ This point is rather similar to one of the more serious objections to Lewis' modal realism: 'the problem of explaining what these [worlds] would have to do with modality if there were any of them.', from Peter van Inwagen, 'Plantinga on Trans-World Identity', in Peter van Inwagen and James E. Tomberlin (eds), Alvin Plantinga (Dordrecht: D. Reidel Publishing Company, 1985), p. 119
} 
an author in such-and-such an act of creation), the author could be mistaken, as above. Conan Doyle could have written slightly incorrect stories about the Meinongian nonexistent Frederick Holmes, or the Platonic abstractum Frederick Holmes, without the actual content of the stories being any different than they were. In each of these cases, Frederick Holmes is the same kind of thing as Sherlock Holmes. But Frederick Holmes is, intuitively, not a fictional character. On eternalist views, Sherlock Holmes thus cannot be a fictional character either. The theorist is left with 3 options: deny the truth of (3) ('Sherlock Holmes is a fictional character'), reject realism about fictional characters, or become a creationist about fictional characters. My personal inclination is to accept both (3) and be an ontological realist, but, if it could be shown that creationism about fictional characters is incoherent, this argument would succeed in showing realism to be false.

The foregoing discussion can be used to consider a problem for any creationist view of fiction: that of determining when a fictional character comes into existence. No eternally existing object can be a fictional character, and I believe that there are fictional characters (of which Sherlock Holmes is one). There is therefore a time at which Sherlock Holmes came into existence. One argument against the eternalist view is that an author cannot decide what an eternal object is like, but can decide what a character is like according to a story. However, this does not necessarily tell us what a character is like simpliciter. ${ }^{83}$ How, then, do

\footnotetext{
${ }^{83}$ It seems possible that, even if artefactualism is the correct theory of fictional objects, the best way to find out what is true according to a story may be to make-believe that Lewis' theory is correct. This may even be the way for abstractists to deal with critical statements that assume that fictional characters have a mental life of their own, such as 'Holmes would not have needed tapes to get the goods on Nixon': it is true according to the story, in the Lewisian sense of 'according to the story’. Cf. Kit Fine, 'The Problem of Non-Existents I. Internalism', Topoi, vol. 1, 1982, p. 98:
} 
we find out? What is it that determines what Sherlock Holmes is like (such as, that he is a fictional character)? The answer to this is that what Sherlock Holmes is like is determined by our critical practices regarding fiction. This is appropriate, because, as discussed earlier, it is statements made in our critical practices that provide the best evidence for there being fictional characters. Conan Doyle produced stories that contained Sherlock Holmes, who according to the story is a human and a detective. Our critical practices regarding fiction determined that because of Conan Doyle’s stories, Sherlock Holmes is a fictional character. This means that there was such a fictional character as Sherlock Holmes as soon as our critical practices could be directed at Conan Doyle's stories, and no sooner. ${ }^{84}$ The most reasonable time to suppose that this happened is when the first of the Conan Doyle stories including Sherlock Holmes was published. Fictional characters are created on the publication, or the making publicly accessible, (in communities in which our critical practices regarding fiction exist) of the stories of which they are characters. This owes much to the notion that fictional characters are created by what Stephen Schiffer calls the 'hypostasizing' use of fictional names. ${ }^{85}$ The hypostasizing use of a fictional name is the use of a fictional name in our critical practices, to discuss an actual fictional character, as opposed to the use of it to describe the content of a fiction.

\footnotetext{
'Finally, the internalist theory, though not correct as a theory of objects, may correctly be interpreted as a theory of the contents of those objects and, as such, may usefully be grafted onto the more satisfactory theory that is to follow.'

${ }^{84}$ This appears consistent with the suggestion of Zalta that our talk about fictional characters should be seen as quantifying over patterns of use. There are no patterns of use of the name 'Sherlock Holmes' until there are critical practices directed at Conan Doyle's stories. See Edward N. Zalta, 'The Road Between Pretense Theory and Abstract Object Theory' in A. Everett and T. Hofweber (eds), Empty Names, Fiction, and the Puzzles of Non-Existence (Stanford: CSLI Publications, 2000), pp. 25-29

${ }^{85}$ Schiffer, 'Language-Created Language-Independent Entities', p. 157
} 
There is an objection that could be made to this argument. If we believe that Sherlock Holmes is a fictional character, and that Sherlock Holmes is created, we are likely to believe

(7) Sherlock Holmes was created by Sir Arthur Conan Doyle.

However, if Sherlock Holmes was created on the publication of Conan Doyle’s stories, it seems as if Strand Magazine should get some of the credit as well. This is counterintuitive, and seems clearly false. However, it is not a consequence of this explanation of creation that publishers create characters as much as authors do. The publication of a work of fiction into a community in which our critical practices regarding fiction exist is the proximate cause of that character's existing. The fictional character Sherlock Holmes began to exist when Strand Magazine published Conan Doyle’s stories. There are, though, further causes along the way to the fictional character Sherlock Holmes being brought into existence. Strand Magazine’s publication of the stories was presumably caused by various things, but the one event which is the original cause of the publication of the stories is Conan Doyle's writing of them. (7) is true because Conan Doyle's writing of the stories is the cause of those stories (and not other stories featuring a detective called Frederick Holmes) being published. If the same stories had first been published at a different time, or in a different place, the same characters would still have existed. If the author's actions had been different, then different characters would have existed. Creationism is thus consistent with the belief that a fictional character is created by the author of the stories in which that character appears. 
Another potential problem with this account of creation is related to the use of creationism as a means to individuate fictional characters. If we are individuating fictional characters by their acts of creation, then we need different acts of creation for different characters. However, if fictional characters are created by having works including them made publicly accessible, then all of the characters in a book will be created in the same act of creation, and will thus (on this account) be the same character. It is clearly not the case that any analysis of fiction would want to imply that Sherlock Holmes and Watson are the same character. This problem can be dealt with similarly to the previous one. Though Holmes and Watson come into existence at the same time, on the publication of the relevant stories, the acts of Conan Doyle that were the original cause of their coming into existence were different. The two can have their histories traced back to different starting points. This response may not be entirely satisfactory. It seems possible that Conan Doyle could have conceived of the detective and his chronicler together, and, even if he did not, it is not entirely clear how we should go about individuating an author's acts of imagination. Perhaps it is in fact the case that Holmes and Watson become publicly accessible at different times, by first appearing at different stages of the book.

\subsection{Individuals}

Fictional characters are not types, or kinds, or properties, but individuals. Types are the kinds of things that can have tokens, and fictional characters are not. Properties are the kinds of things that can be predicated of individuals, and fictional characters are not. 
Part of the motivation for this view comes from the observation that fictional characters are created, whereas types and properties are generally thought to exist necessarily and eternally if they exist at all. Thinking of fictional characters as actual existents and not just sets of possibilia is also motivation in this direction.

Those who argue that fictional characters are not individuals but types are role realists, such as Nicholas Wolterstorff ${ }^{86}$ and Greg Currie. ${ }^{87}$ Wolterstorff claims that characters are 'person-kinds' ${ }^{88}$ Kinds, according to Wolterstorff, are mapped one-to-one with properties: for every property $k$ there is the associated kind $K .^{89}$ Fictional characters are person-kinds (not persons of a certain kind) that are maximal components of the world of a work of fiction, where the world of a work of fiction is a certain state of affairs. ${ }^{90}$ Of course not all fictional characters are ascribed the property of being persons at all, but Wolterstorff's theory can easily account for other cases. This view implies that the properties that are ascribed to a character are essential to that character, because an example of the person-kind $K$ could not exist without its having exactly the property $k$.

Currie claims that fictional characters (at least in what he calls the 'transfictive' uses of their names, or, roughly, in critical claims about them) are roles. ${ }^{91}$ Within his possible-worlds analysis of fiction, he argues that 'there is a (partial) function

\footnotetext{
${ }^{86}$ Nicholas Wolterstorff, Works and Worlds of Art (Oxford: Clarendon Press; New York: Oxford University Press, 1980)

${ }^{87}$ Gregory Currie, The Nature of Fiction (Cambridge: Cambridge University Press, 1990)

${ }^{88}$ Wolterstorff, Works and Worlds of Art, p. 144

${ }^{89}$ ibid., p. 47

${ }^{90}$ ibid., pp. 145-146 .Wolterstorff does argue for the conception of fictions as worlds, but that point is not critical to this discussion.

${ }^{91}$ Currie, The Nature of Fiction, pp. 171-172
} 
from worlds to individuals that picks out Holmes in each world where somebody is Holmes, and the value of this function for a world-argument is the individual, if there is one, who satisfies [the definite description which Holmes satisfies], ${ }^{92}$ This function is what Currie calls the Holmes role. Currie notes that this role is unoccupied in the actual world (which is what he takes us to mean when we say that Sherlock Holmes does not exist), but is occupied in other possible worlds. A role is an abstract, theoretical entity, so Currie's views have some similarity to van Inwagen’s. For instance, according to Currie, a fictional character cannot have the property of being fat (a role cannot be fat), but can be ascribed the property in a fiction. ${ }^{93}$ It is in fact not entirely clear what it would be to ascribe fatness to a function from worlds to individuals. Presumably it is to say that anyone who occupies the role must be fat, but this seems to be constitutive of the role in a way in which ascribed properties of fictional characters are not constitutive of those characters. However, this is not an argument against role realism, but just a possible reason why it should not be conflated with other realisms about fictional characters.

There is something unusual about the claim that fictional characters are kinds or types. It is that these things are traditionally thought to have tokens, or to be realised by some individual. Fictional characters, on the other hand, cannot have real tokens. Even if there is a person with all of the properties ascribed to a certain fictional character, he is still not a token of that character. ${ }^{94}$ For a person to be that character, the relevant stories would have to be about them, and, given that the stories are fictional, they are not about real people at all. Fictional

\footnotetext{
92 ibid., p. 172

93 ibid., p. 173

${ }^{94}$ For the reasons given by Kripke, Naming and Necessity, p. 158
} 
characters are thus untokenable types, or unrealisable roles. Untokenable types do not seem like a helpful addition to our ontology, and do not help us to draw out the similarities between fictional characters and other things.

Another problem with the view of fictional characters as kinds is pointed to by Wolterstorff. This problem is that kinds could not have been different than they are. The properties that an individual must have to be an example of a kind are essential to that kind. ${ }^{95}$ Two difficulties for the view of characters as kinds follow from this. The first is that, given that Wolterstorff believes that every property a character is ascribed is essential to it, it means that no fictional character could have been ascribed different properties than it is. What would seem to be a character being ascribed different properties would in fact, according to Wolterstorff, be the delineation of a different person-kind, and so a different character. This goes against our intuitions. It does not seem to be the case that, had Conan Doyle ascribed Holmes slightly different properties, he would have in fact created a completely different character. All he would have in fact done was ascribe the very same character different properties. The second difficulty created by the identity conditions for kinds is that of providing identity conditions for characters across different stories. Wolterstorff himself does note this problem, and attempts to provide a solution for it. He writes that 'having written one book, Conan Doyle offered the further adventures of Sherlock Holmes. And then there is the related phenomenon of different writers telling the story of Hercules, of Hamlet, of Don Juan, of Faust—-telling it differently. ${ }^{96}$ If the properties ascribed to a character are essential to it, then different stories,

\footnotetext{
${ }^{95}$ Wolterstorff, Works and Worlds of Art, p. 148

${ }^{96}$ ibid.
} 
which will seemingly ascribe the character different properties, must in fact be about different characters. Wolterstorff's solution to this is to draw a 'rough and ready’ distinction between properties that are more or less central within a character. ${ }^{97}$ The person-kind which possesses the central core of properties of the character is different from each of the person-kinds in the particular books. It is not a maximal component of any of the books, but it is a component that contains each of the maximal components of the different books that we would want to identify as the same character. ${ }^{98}$ Thomasson has argued against this account of identity across fictions. ${ }^{99}$ For this means of identification to work, we need to be able to pick out the central core of properties. However, it is not clear what they must be. Wolterstorff and Thomasson each discuss the example of Faust. Wolterstorff claims that he has the essential properties of being called Faust, signing a pact with the devil, and so forth. ${ }^{100}$ Thomasson notes that it seems possible for even these conditions to fail to be met by a character that we would intuitively want to say is the same Faust character. Someone could write a fiction according to which Faust turns down the devil's offer, or a fiction in which someone called 'Phaust' does not. ${ }^{101}$ If, however, we want to go down to an even smaller central core of properties than this (maybe being a man and being intelligent), we will have too few properties, and will end up identifying works as about the same character when they are in fact clearly about different characters. ${ }^{102}$ This dilemma is a direct consequence of role realism about fictional characters. Because this view claims that fictional characters are kinds,

\footnotetext{
97 ibid., p. 149

98 ibid., p. 149

99 Thomasson, Fiction and Metaphysics, pp. 58-61

${ }^{100}$ Wolterstorff, Works and Worlds of Art, p. 149

101 Thomasson, Fiction and Metaphysics, p. 60

102 ibid.
} 
and kinds have all of the properties within them essentially, this view cannot provide a way to identify characters across fictions. 


\section{Works of Music}

The works of music that will be discussed in this chapter are works of pure instrumental music. Though there are obviously far more works of music than this (and I believe that artefactualism applies to the others too) the majority of the literature on the ontology of music is on works of pure instrumental music, so this will be my focus.

\subsection{Existence}

Unlike the case of fictional characters, there is not very much dispute that works of music exist (alternatively, that there are works of music). The philosopher who argues that there are works of music is not going against our intuitions. There are obviously true sentences that refer to works of music, and true sentences that quantify over works of music. An example of the first is

(8) In This House, On This Morning is a suite. ${ }^{103}$

An example of the second is

(9) There are more than thirty symphonies composed by Mozart. ${ }^{104}$

Both (8) and (9) seem to be straightforwardly true and are usually taken at face value. This implies the existence of In This House, On This Morning and Mozart's symphonies. This strategy of course generalises to other works of music as well.

\footnotetext{
${ }^{103}$ Julian Dodd, Works of Music: An Essay in Ontology (Oxford: Oxford University Press, 2007), p. 9 ${ }_{104}$ ibid., p. 9
} 
There have been some philosophers who have suggested that works of music do not exist (or at least, if they do, they are something rather different from what we have thought). The views that will be discussed here are eliminativism, nominalism and two types of action theory, which are forms of reductionism, and pretense fictionalism.

Ross P. Cameron has argued that the world does not contain any objects (concrete or abstract) with which works of music can be identified, even though many of the sentences we utter about works of music are literally true. ${ }^{105}$ On this account, (8) is true, but, as a matter of ontological fact, there is no thing which is In This House, On This Morning. Cameron argues that when we are making ontological claims, or trying to 'describe how the world is at its fundamental level', our sentences are not in English but in 'Ontologese', and that affirming the truth of (8) does not contradict saying, in Ontologese, that there is no thing which is In This House, On This Morning. ${ }^{106}$ Accepting this view would require us to accept that sentences have other than their usual meanings when they are used in ontological discussions, which is not an appealing idea. Another eliminativist about works of music is Richard Rudner, who claims that our ordinary locutions about works of music are shorthand for talk about performances. ${ }^{107}$ For instance, he writes that 'the sentence "Beethoven's Fifth Symphony is good but this is a bad rendition of it," could be taken as an ellipsis for "there is a musical rendition called Beethoven's Fifth Symphony which is

\footnotetext{
${ }^{105}$ Ross P. Cameron, 'There Are No Things that are Musical Works', British Journal of Aesthetics, vol. 48, no. 3, July 2008, p. 295

${ }^{106}$ ibid., pp. 300-301

${ }^{107}$ Richard Rudner, 'The Ontological Status of the Esthetic Object', Philosophy and Phenomenological Research, vol. 10, no. 3, March 1950, p. 385
} 
pleasing esthetically but this musical rendition, while similar to it in important respects, is esthetically displeasing." ${ }^{108}$ However, it is not at all clear that the claim ‘there is a musical rendition called Beethoven's Fifth Symphony’ helps us to do away with works of music. Eliminativism about musical works is unsuccessful.

Nominalists want to do away with abstracta altogether, and to identify the things we think are abstract objects with concrete objects of some kind. In the case of works of music, the most plausible concreta to do this with are performances (or sets thereof) and scores, or both.

The most prominent nominalist about works of music was Nelson Goodman. Goodman believed that a work of music was 'the class of performances compliant with a character'. ${ }^{109}$ By a character Goodman meant a score, which was a character in a notational system that was such that it may have compliants. ${ }^{110}$ A musical work is thus the class of all those concrete objects that are compliant with the score. (Goodman also believed that classes were fictions, so presumably musical works were too.) Compliance for Goodman is exact compliance, so a work of music is the class of all note-perfect performances of the work. Not only does a score uniquely determine a class of performances, but the class of performances also uniquely determines the score, which can only happen if each member of the class complies with the score exactly. ${ }^{111}$ Goodman claims that precise compliance such as this is the only way to preserve the

\footnotetext{
108 ibid.

${ }^{109}$ Nelson Goodman, Languages of Art: An Approach to a Theory of Symbols (New York: Bobbs- Merrill, 1968), p. 210

${ }^{110}$ ibid., p. 177

111 ibid., p. 178
} 
identity of the work through a chain of scores and performances, and is thus necessary even though it is unintuitive.

Arguing against nominalism, Stephen Davies writes

Many of the things we say about musical works are not reducible to claims about performances or about sets of performances. For example, consider the following: 'With his Fifth, Beethoven fully entered his mature period', or: 'Beethoven's First was influenced by the symphonies of Mozart and Haydn'. Moreover, we group performances into sets in terms of the works they are of and no other principle allows us to group them as we do, so the individuation of performances presupposes the existence of works, not vice versa. ${ }^{112}$

There are further objections to the account of musical works as classes (or sets) of performances. One is that there is only one null class, which implies that all unperformed works are identical with each other. ${ }^{113}$ This is clearly false, as it is obvious that there are a number of unperformed works. ${ }^{114}$ Another problem is that sets have their membership essentially. ${ }^{115}$ However, works of music can have more, or fewer, or different performances to those they do have, and can thus not be identified with sets. A third problem is that it is often thought that a set can only exist when its members exist, so, given that different performances of a work occur (and therefore exist) at different times, the set of all and only the things that are ever performances of a particular work of music does not exist. ${ }^{116}$ There is no existent set that matches the set that a nominalist would like to

\footnotetext{
${ }^{112}$ Stephen Davies, 'Ontologies of Musical Works', in his Themes in the Philosophy of Music (Oxford: Oxford University Press, 2003), p. 31

${ }^{113}$ Wolterstorff, Works and Worlds of Art, pp. 44, 100

${ }^{114}$ Perhaps this problem could be avoided if we treated a work as the set of all of its performances and all of its scores. Any 'work' that does not have any performances or scores ('embodiments') presumably doesn't exist, and, given that there are no non-existent works, this might get around this objection.

${ }^{115}$ Wolterstorff, Works and Worlds of Art, pp. 44, 100

${ }^{116}$ ibid., p. 100
} 
identify a musical work with. A possible response to claims such as these, given by Stephen Davies, is to suggest that what matters on Goodman's account is that each individual performance (each member of the putative set) is 'a complete and accurate expression of the work', not that we can pick out the set. ${ }^{117}$ Mentioning a class is helpful because it reminds us that work-preserving performances can differ, but the class that really counts is the class of all performances which would be instances of the work, or the work's possible extension. ${ }^{118}$ The problem with this solution is that it cannot be faithful to Goodman, who would have been even more hostile to classes of possibilia than he would have been to classes simpliciter (though this shouldn't stop anyone else from appropriating this view.)

A rather different view on the metaphysical status of musical works is that of Gregory Currie and David Davies. ${ }^{119}$ They argue that a work of music (or any other work of art) is identical to the action of a composer (or artist). They differ in that Currie thinks that the work is an action-type of which the composer's particular act is a token, whereas Davies thinks it is an action-token. Every other view on the ontology of music supposes that if there are any musical works, they will be objects in their own right. However, according to Currie and Davies, the object that would generally be held to be the work is instead the 'work-focus'. According to Davies, works of art 'belong to the class of performances whereby a content is articulated through a vehicle on the basis of shared understandings' ${ }^{120}$ The major reason for holding the view that works of art are

\footnotetext{
117 Stephen Davies, Musical Works and Performances: A Philosophical Exploration (Oxford: Clarendon Press, 2001), p. 41

118 ibid., p. 41

${ }^{119}$ Gregory Currie, An Ontology of Art (New York: St. Martin’s Press, 1989); D. Davies, Art as Performance

${ }^{120}$ D. Davies, Art as Performance, p. 80
} 
performances is that when we appreciate artworks we are appreciating a certain kind of achievement of the artist. ${ }^{121}$ Our recognising what a composer has done and ascribing the appropriate properties to the work requires, according to Davies and Currie, that we treat works as actions. The main problem with this view is that it is not at all plausible that a work of music could be identified with a compositional action. For instance, the view implies that we cannot hear a work of music unless we have heard the composer composing it, or that the work ceases to exist (though the work-focus remains) once the work has been completed. I will thus not be focusing on Davies’ and Currie’s views.

A fictionalist about musical works is Andrew Kania. ${ }^{122}$ He is led to this view by a focus on how we should study the ontology of music. He argues that ontologists of music should be descriptivist. Descriptivists treat the ordinary discussions of art by artists and critics as the best evidence we have for doing ontology of art. As Rohrbaugh puts it (and with which Kania agrees), '[o]ntologies of art are beholden to our artistic practices' ${ }^{123}$ This constraint rules out views according to which works of art are things much different from what we think they are. It could also be used to rule technical metaphysical discussions out of the ontology of art. Kania writes:

we may be justified in thinking that our ontological theories of art (as with our theories of everything else) must obey the laws of logic, but if they are truly descriptive they are not beholden to anything else, apart from our artistic practice, in ways already discussed. If the best rational reconstruction of the

\footnotetext{
${ }^{121}$ Currie, An Ontology of Art, p. 72

${ }^{122}$ Andrew Kania, 'The Methodology of Musical Ontology: Descriptivism and Its Implications', British Journal of Aesthetics, vol. 48, no. 4, Oct. 2008, pp. 426-444

${ }^{123}$ Rohrbaugh, ‘Artworks as Historical Individuals', p. 179
} 
ontological conception of artworks implicit in artistic practice is that they are $\mathrm{X}$, $\mathrm{Y}$, and $\mathrm{Z}$, then artworks are in fact the kind of thing that is $\mathrm{X}, \mathrm{Y}$, and $\mathrm{Z} .{ }^{124}$

It seems strange that, given this (sensible) discussion of what it is that ontologists of art should be finding out, Kania goes on to defend fictionalism. The fictionalism that Kania defends is pretense fictionalism, according to which statements about musical works are to be understood in the spirit of a pretense. Kania claims that works of music are 'intentional inexistents'. ${ }^{125}$ To say that works of music are intentional inexistents is to say that '(i) there are no such things, either outside the mind in the concrete or abstract realms, or inside the mind, but that (ii) there is a quite robust shared system of representations of such things. ${ }^{126}$ Kania suggests that the ongoing and seemingly intractable disputes that metaphysicians have had about the ontological status of musical works may be evidence that there are not any, ${ }^{127}$ but this is hardly conclusive. By parity of reasoning, we could discover that, say, causation does not exist either. Maybe this is correct, but it does not seem as if the inability of philosophers to agree on a single answer to the question of its nature should be part of the evidence. Kania also draws an analogy between music and language (which is argued by Georges Rey, who Kania cites, to be an intentional inexistent). He claims (though without great confidence) that 'the ways musical ideas are disseminated through works is analogous to the way ideas are disseminated through language: they are set down in writing, and communicated through ‘utterances’ (performances), none of

\footnotetext{
${ }^{124}$ Kania, 'The Methodology of Musical Ontology', p. 438

${ }^{125}$ Georges Rey, 'The Intentional Inexistence of Language — But Not Cars', in Robert Stainton (ed.), Contemporary Debates in Cognitive Science (Oxford: Blackwell, 2006), pp. 237 - 255, in Kania, 'The Methodology of Musical Ontology', p. 439

${ }^{126}$ Kania, 'The Methodology of Musical Ontology', p. 439

127 ibid., p. 440
} 
which need match the structure of the work perfectly., ${ }^{128}$ The major argument that Kania gives for fictionalism is the Oracle argument. He does this by writing that it 'would make no difference if there were no musical works, strictly speaking, as long as we all continued to behave as if there were. ${ }^{129}$ Furthermore, he claims that there is no need to change our practices regarding musical works, which are valuable and successful as they are. ${ }^{130}$ This argument is intended to show that our practices need not ontologically commit us to there being works of music. Kania seemingly puts forward this view with the intention of stopping some fruitless philosophical disputes. He claims that he has left plenty of room for discussion of how we conceive of musical works, which is really what ontologists of art should be discussing anyway. However, the clash between his own view and the ordinary critical practice of the discussion of musical works is acute enough to make his own view highly questionable. It is surely true that those engaged in critical discussions of works of music would all agree that the works of music which they are discussing exist, as well as our ordinary musical practices.

\subsection{Creation}

We hold the intuition that works of music are created by their composers. Indeed, Jerrold Levinson has called this 'one of the most firmly entrenched of our beliefs concerning art. ${ }^{, 131}$ Levinson also believes that part of our respect for composers comes from our belief that they 'truly add to the world, in company with cake-

\footnotetext{
${ }^{128}$ ibid.

129 ibid.

${ }^{130}$ ibid., pp. 442-443

${ }^{131}$ Levinson, 'What a Musical Work Is', p. 8
} 
bakers, house-builders, law-makers, and theory-constructers’. ${ }^{132}$ However, creationism about works of music is a view that appears to conflict with our ordinary views on abstract objects. As we have already seen, Harry Deutsch described this kind of problem as the 'creation problem'. This can be applied to the case of works of music as follows:

1. Works of music are abstract objects.

2. Creating an object entails bringing it into existence or causing it to exist.

3. Abstract objects cannot stand in causal relations.

4. Therefore, works of music are not created. ${ }^{133}$

Because this argument is valid, philosophers have the options of rejecting one or more premises or accepting the conclusion. Deutsch's own solution is to deny the second premise, but this account is unsuccessful, for the reasons discussed in the previous chapter (on fictional characters).

Platonist theories of the ontology of music cannot account for the created status of works of music. There are two ways a Platonist can deal with this. They can either deny that musical works are created, or they can provide a modified Platonist account to allow for creation. It will be shown that both of these alternatives fail.

Those philosophers who commit to a strict Platonism about musical works must deny that musical works are created. Philosophers who take this line include

\footnotetext{
132 ibid.

${ }^{133}$ Deutsch, ‘The Creation Problem’, p. 210
} 
Peter Kivy ${ }^{134}$ and Julian Dodd. ${ }^{135}$ The view of Kivy is that the activity which composers of works of music are engaged in is not creation, but discovery. To Kivy, the key to our judgements of the sort that Levinson urges is not that the composer is a creator, but that he is creative. A composition is thus a 'creative discovery’, of similar kind to scientific or mathematical discoveries. ${ }^{136}$ There are two parts to this claim (creativity, and discovery), and there are problems with each. First, it is clear that creation and creativity are quite different concepts. ${ }^{137}$ Creation seems to be an all-or-nothing matter: an entity is either created by such a person or it is not. Creativity, however, seems to be a matter of degree. It is not at all paradoxical to say that some creations are more creative than others. If our ordinary claims about creation were really just claims about creativity, it is at least not obvious that this should be so. As Predelli notes, '[t]he fact remains that our intuitions on this subject do not rest satisfied with the claim that artists are creative: we also unequivocally believe that they create'. ${ }^{138}$ Showing that a composer is truly thought to be creative is thus not enough to give us a reason to doubt that works of music are created.

The second part of the claim made by Kivy and Dodd is that works of music are discovered. There is an epistemological difficulty for this account. Platonists believe that abstracta cannot be created because creation requires causal interaction, and we cannot causally interact with abstracta. However, it is not

\footnotetext{
${ }^{134}$ Peter Kivy, 'Platonism in music: A kind of defense', 'Platonism in music: Another kind of defense', and 'Orchestrating Platonism', all in his The Fine Art of Repetition (Cambridge: Cambridge University Press, 1993), pp. 35-58, 59-74, and 75-94 respectively ${ }^{135}$ Julian Dodd, Works of Music; 'Musical Works as Eternal Types', British Journal of Aesthetics, vol. 40, no. 4, Oct. 2000, pp. 424-440

${ }^{136}$ Kivy, 'Platonism in music: A kind of defense', pp. 39-43

${ }^{137}$ Kivy himself does seem to note this in 'Platonism in music: Another kind of defense', pp. 248-249

${ }^{138}$ Predelli, ‘Musical Ontology and the Argument from Creation’, p. 282
} 
immediately clear that discovery does not require causal interaction. It is certainly the case that discoveries of concrete objects such as continents or plants require causal interaction with those objects. However, the analogy that Dodd and Kivy choose to draw is with cases of mathematical and scientific discoveries. Part of the purpose of this is to show that we can still regard the achievements of composers as great even if they are not creators. Levinson had claimed that composers would lose 'a small part of the glory' associated with their achievements if musical works were considered to exist eternally. ${ }^{139}$ An analogy to the discoveries of science is supposed to dispel this worry: as Kivy writes, '[i]n the company of Newton, after all, one is hardly slumming' ${ }^{140}$ The analogy is also presumably supposed to help to explain how we can see the act of composing as a discovery. However, there is a crucial disanalogy between the cases of science or mathematics and music which suggests that the action of composers is not best seen as discovery. R.A. Sharpe has argued that what genuine cases of discovery have in common is the possibility of being mistaken. ${ }^{141}$ Scientists (and also the discoverers of concrete objects) are discovering things or truths that are there anyway, and can thus be in error as to what they are or what they are like. This is not the case for composers. There is no truth discovered in the composition of a work of music, so the composer does not have the possibility of error in the way that a scientist might. ${ }^{142}$ Composers cannot misidentify their works, so they do not have the possibility of error in the

\footnotetext{
${ }^{139}$ Levinson, 'What a Musical Work Is', p. 9

${ }^{140}$ Kivy, 'Platonism in Music: A kind of defense', p. 40

${ }^{141}$ R.A. Sharpe, 'Could Beethoven have 'Discovered' the Archduke Trio?', British Journal of Aesthetics, vol. 41, no. 3, July 2001, p. 326

${ }^{142}$ John Andrew Fisher, 'Discovery, Creation, and Musical Works', Journal of Aesthetics and Art Criticism, vol. 49, no. 2, Spring 1991, p. 133
} 
way that the discoverer of some concrete object might. ${ }^{143}$ It is not clear what other models of discovery are available to the Platonist. ${ }^{144}$ Dodd has responses to these arguments. The first of these is to say that the discovery of a musical work has 'aspects in common with both discoveries in mathematics and discoveries of a more common-or-garden kind. ${ }^{145}$ One thing to be noted with this response is that it makes the act of composition a unique kind of discovery. It is possible that composition is in some way unique, but this still makes it questionable what the analogies between music and other discoveries show. For us to see that the discovery of a musical work is relevantly similar to the discovery of other things, the Platonist needs to give us a fuller account of this discovery than has yet been done. Dodd's other response is to claim that the possibility of error only applies to certain discoveries, namely, those that could be called discoveries by enquiry. ${ }^{146}$ However, this again seems rather ad hoc. If the discoveries that composers make are so unlike the discoveries that Platonists want to draw analogies with, then we still lack any evidence that composers should be seen as discoverers.

The most prominent proponent of the modified Platonist view of the ontology of musical works is Jerrold Levinson. Levinson sees the intuitive pull in treating works of music as sound structures, but argues that sound structures simpliciter cannot be identical with musical works. Instead, he identifies musical works with

\footnotetext{
${ }^{143}$ Sharpe, 'Could Beethoven have 'Discovered' the Archduke Trio?', p. 326

${ }^{144}$ One option may be to follow Harry Deutsch, 'The Creation Problem', in suggesting that the plenitude of abstracta from which the composer can choose explains why it is impossible for a composer to be in error.

${ }^{145}$ Dodd, Works of Music, p. 118

${ }^{146}$ ibid., p. 120
} 
what he calls 'indicated structures' ${ }^{147}$ His reasons for not believing that musical works are just sound structures are first, that sound structures cannot be created, and second, that there is more to the individuation of musical works than just how they sound. ${ }^{148}$ He argues for the second claim as follows:

(1) If musical works were just sound structures, then, if two distinct composers determine the same sound structure, they necessarily compose the same musical work. (2) But distinct composers determining the same sound structure in fact inevitably produce different musical works. Therefore, musical works cannot be sound structures simpliciter. ${ }^{149}$

The evidence for this is that some aesthetic and artistic properties of a work of music are closely connected to the musico-historical context in which the piece was composed, and different composers invariably differ in musico-historical context, even if they produce identical sound structures. ${ }^{150}$ Given these claims, Levinson needs to find an account of what a musical work is that can meet both the requirement of creatability, and the requirement of fine individuation (according to which identical sound structures composed in different musicohistorical contexts count as different works).

Levinson's account is that works of music are not pure sound (and performance means) types, but 'indicated' types. A musical work, according to Levinson, is a sound (and performance means) structure-as-indicated-by- $X$-at- $t$, where $X$ is the composer and $t$ the time of composition. ${ }^{151}$ Levinson claims that this meets the creatability requirement:

\footnotetext{
${ }^{147}$ Levinson, 'What a Musical Work Is', p. 20

${ }^{148}$ He also claims that means of performance is essential to a musical work, but cannot be to a sound structure, so the two must be different. This aspect of Levinson's view is frequently ignored in the literature, and is not important to what I'm discussing.

${ }^{149}$ Levinson, 'What a Musical Work Is', p. 10

150 ibid., p. 20. This is analogous to Borges' famous Pierre Menard case.

151 ibid.
} 
An S/PM structure-as-indicated-by-X-at- $t$, unlike an S/PM structure simpliciter, does not pre-exist the activity of composition and is thus capable of being created. When a composer $\theta$ composes a piece of music, he indicates an S/PM structure $\psi$, but he does not bring $\psi$ into being. However, through the act of indicating $\psi$, he does bring into being something that did not previously existnamely, $\psi$-as-indicated-by- $\theta$-at- $t_{1}$. Before the compositional act at $t_{1}$, no relation obtains between $\theta$ and $\psi$. Composition establishes the relation of indication between $\theta$ and $\psi$. As a result of the compositional act, I suggest, the world contains a new entity, $\psi$-as-indicated-by- $\theta$-at- $t_{1}$. Let me call such entities indicated structures. And let me represent indicated structures by expressions of form "S/PM* $x^{*} t . "$ It is important to realize that indicated structures are entities distinct from the pure structures per se from which they are derived. Thus, in particular, $\psi^{*} \theta^{*} t_{1}$ is not just the structure, with the accidental property of having been indicated by $\theta$ at $t 1-\psi^{*} \theta^{*} t_{1}$ and $\psi$ are strictly non-identical, though of course related. $\psi^{*} \theta^{*} t_{1}$, unlike $\psi$, can be and is created through $\theta^{\prime \prime}$ s composing. ${ }^{152}$

It is not immediately clear that Levinson is right that indicated types can be created. As Predelli has noted, 'in the absence of evidence to the contrary, it does not seem to be the case that, if you show me the tallest building on campus, you thereby bring into existence a new object, that is, the building-as-shown-byyou. ${ }^{153}$ In fact, it seems that if we accept Levinson's view we will get a lot of new entities in our ontology: America-as-discovered-by-Columbus, penicillin-asdiscovered-by-Fleming, and so forth. ${ }^{154}$ Levinson in fact notes this, and just suggests that there is no need for us to recognise penicillin-as-discovered-byFleming, but there is a need, in discussing the ontology of music, to recognise indicated types like sound-structures-as-indicated-by-composers. ${ }^{155}$ Levinson has

\footnotetext{
152 ibid.

${ }^{153}$ Predelli, 'Musical Ontology and the Argument from Creation', p. 289

${ }^{154}$ This is similar to a suggestion in Gregory Currie, 'Review of Music, Art, and Metaphysics', Philosophy and Phenomenological Research, vol. 53, no. 2, June 1993, p. 473, and in Currie, An Ontology of Art, p. 58

155 Jerrold Levinson, 'Review of An Ontology of Art', Philosophy and Phenomenological Research, vol. 52, no. 1, March 1992, p. 219
} 
to do more than assure us that there is some new object to prove that it is so. It is easy to think that all creation on Levinson's account involves is moving a preexisting entity from one ontological category to another. This is not real creation, as is evidenced by the fact that the view is shared by Nicholas Wolterstorff, who is a Platonist. Wolterstorff writes that ' $[\mathrm{w}]$ hat the composer does must be understood as consisting in bringing it about that a preexistent kind becomes $a$ work—specifically, a work of his. ${ }^{, 156}$ Levinson's view of composition could be seen as identical to this.

One of the problems that the claim that musical works can be identified with types has is that types are not creatable, so, if indicated types are types, then they are not creatable either. Dodd in fact explicitly responds to Levinson (as part of his defense of Platonism) in this way. The disagreement here is one over the nature of types. Levinson believes that types only exist when it is possible for them to have instances or tokens. If this is the case, then musical works would come into existence on the actions of the composer, because until then it would be impossible for there to be a token of the indicated type (that is, a token performance of the work which is appropriately related to the relevant act of indication). Dodd conversely argues that a type exists whenever its propertyassociate exists. ${ }^{157}$ The property-associate of a type $K$ is being a $k$, and it is the property that anything must have to be a (properly formed) token of $K .{ }^{158}$ The property-associate of the indicated type $\psi$-as-indicated-by- $\theta$-at- $t_{1}$ is 'having the sonic structure determined by $\psi$, and also being produced in a way that is properly connected to [ $\theta$ 's act of indication at $t_{1}$ ', and, because Dodd believes

\footnotetext{
${ }^{156}$ Wolterstorff, Works and Worlds of Art, p. 89

${ }^{157}$ Dodd, Works of Music, pp. 104-105

${ }^{158}$ ibid., p. 49
} 
that all properties exist at all times, this property must exist at all times. ${ }^{159}$ This implies that the indicated type with which Levinson wanted to identify the work exists at all times as well, and therefore cannot be created. Because Levinson accepts that types cannot be created, this argument is a serious problem for his view.

Robert Howell has responded to Dodd in defense of the indicated-type view. ${ }^{160}$ The key point in Howell's defense is that indicated types cannot exist until the entities which they 'essentially involve' exist. ${ }^{161}$ Because works of music essentially involve their composers and the composer's mental acts, they do not exist before those acts occur. This means that they come into existence at some time, which is to say that (given that their coming into existence is deliberately caused) they are created. Dodd's response to this is that it involves an incorrect view of properties. Howell claims that particular entities (such as composers) can be 'involved' in properties, such as 'having the sonic structure determined by $\psi$, and also being produced in a way that is properly connected to [ $\theta$ 's act of indication at $\left.\mathrm{t}_{1}\right]$ '. Dodd disagrees. He argues that it does not make sense to suppose that a concrete particular can be a part of a property, which is abstract. ${ }^{162}$ For a performance to be a token of a musical work, the performance itself (a concrete object) must be appropriately related to the composer, but the work (on Dodd's view a Platonic type) need not be. ${ }^{163}$ If properties are to be construed as abstracta (as both Dodd and Howell believe they should be), then the claim that

\footnotetext{
159 ibid., p. 104

${ }^{160}$ Robert Howell, 'Types, Indicated and Initiated', British Journal of Aesthetics, vol. 42, no. 2, April 2002, pp. 105-127

${ }^{161}$ ibid., p. 113

${ }^{162}$ Dodd, Works of Music, p. 74

163 ibid.
} 
concrete objects can be a part of them is obscure, and Howell's defence of Levinson’s view fails.

An elaboration of Levinson's and Wolterstorff's views has been attempted by James C. Anderson. Following Wolterstorff, Anderson takes works of music to be norm-kinds. Following Levinson, he takes musical works to be created by their composers. He reconciles the two positions (as Wolterstorff does not) by claiming that although descriptive kinds cannot be created, norm-kinds can. ${ }^{164} \mathrm{~A}$ descriptive kind is a kind as ordinarily understood, and a norm-kind is a kind such that it can have properly and improperly-formed instances. ${ }^{165}$ A norm-kind has certain properties normative within it, namely, those properties without which an object cannot be a properly formed example of the kind. ${ }^{166}$ The way that Anderson links this to the creation of musical works is by arguing that the composer of a work creates a norm-kind by treating certain of the properties of a descriptive kind as normative within it. He claims that a created norm-kind is a descriptive-kind which some person at some time has made normative. ${ }^{167}$ Levinson himself cites Anderson's argument as a useful elaboration of his own views: 'Making-normative certainly at least helps explain what indicating consists in, and differentiates it from other activities of an intentional nature directed at abstract structures. ${ }^{168}$ However, this view is no more successful than Levinson's own in showing that a composer has created a new object. Making a

\footnotetext{
${ }^{164}$ James C. Anderson, 'Musical Kinds', British Journal of Aesthetics, vol. 25, no. 1, Jan. 1985, p. 47

${ }_{165}$ Wolterstorff, Works and Worlds of Art, p. 56

166 ibid., p. 7

${ }^{167}$ Anderson, 'Musical Kinds', p. 47

${ }^{168}$ Jerrold Levinson, 'What a Musical Work Is, Again' in his Music, Art, and Metaphysics (Ithaca, N.Y.: Cornell University Press, 1990), pp. 260-261 in Stefano Predelli, 'Musical Ontology and the Argument from Creation', p. 289
} 
descriptive kind into a normative kind would seem to involve selecting a descriptive kind and declaring that certain of the properties within it should be treated as normative. This no more involves bringing into existence an entirely new object than indication does. As Predelli again argues: 'although the composer invites us to consider [the descriptive kind] in a certain manner, and although such an invitation may not have been issued before, it must still be the case that, in the absence of independent considerations to the contrary, the object in question, the descriptive kind, is blessed with eternal (or a-temporal) existence. ${ }^{169}$ This is surely correct. Making a descriptive kind normative is a matter of holding a particular attitude to a thing that is already there, not one of making something new. Anderson's elaboration of Levinson's view thus also fails to meet the creatability requirement.

The account of the creation of works of music that will be defended is one on which works of music are created when their first embodiments are produced, (or perhaps when they are made publicly available, if that is a different thing). The term ‘embodiment’ comes from Guy Rohrbaugh. Embodiments are the physical objects (in the case of works of music, scores, performances, recordings and suchlike) that ground the facts about what the work is like. ${ }^{170}$ The general relationship between a work of music and its embodiments is one of ontological dependence. This makes Rohrbaugh’s view similar to Thomasson's view of fictional characters, according to which they ontologically depend on some concrete objects, such as copies of the books in which they appear. The ontological dependence of works of music on some physical things explains how

\footnotetext{
${ }^{169}$ Predelli, 'Musical Ontology and the Argument from Creation', p. 291

${ }^{170}$ Rohrbaugh, ‘Artworks as Historical Individuals’, p. 191
} 
it is that they are things that exist in time. A work of music can come into existence when its first embodiment is produced (or is made publicly available).

Our evidence for the existence of musical works is that there are true sentences like

(8) In This House, On This Morning is a suite.

This sentence must be true no later than the time at which informed critics can truly utter (8), so the creation of the work must happen no later than this. It can only be truly asserted from the time at which there is some publicly available (where 'publicly available' should be understood quite loosely) object which can ground the truth of (8). This will most likely be at the production of the first score of In This House, On This Morning, though it may be on the production of the first performance of the work (but only if this happens before the score becomes publicly available), or even on the broadcast of a recording of the work (but only if neither a score or a publicly available performance has happened previously). This is analogous to the claim made in the previous chapter regarding fictional characters, which come into existence when a work containing them becomes publicly available. Creating any work of music is a matter of producing some physical object or objects that can ground what the work is like, and inform those who are interested what the work is like.

The view just discussed is quite similar to that held by Robert Howell, although Howell believes that works of music are types. His claims also appear to be 
applicable to the creation of other abstract works of art as well as works of music.

He writes:

Insofar as types arise out of human practices ... those types exist only through those practices. They are thus temporally initiated entities that have instances of their own. The type does not exist until the pattern [an arrangement of parts or features specified by a property] actually takes on the property of being used in the community in the relevant way (or at least of being put in a position so to be used), and the pattern does not take on that property until the community actually so uses it (or is prepared so to use it). ${ }^{171}$

He adds in a footnote:

The type exists when the community is put in the position to produce and recognise the instances. Whether the community then does so depends on further factors. I take the idea of the community's being put in that position quite broadly. It includes cases in which the composer mentally sounds out a piece she never communicates or scores a work that is never performed, even in imagination. However, such a broad construal is not essential to my view. I also allow for types, the existence of which is implied by the existence of those types that community practice explicitly establishes. (If someone establishes baseball or chess, then the community is put in a position to produce and recognize all the relevant plays and moves whether or not they are all ever actually produced. $)^{172}$

Though it has been shown that types cannot be created, so Howell's account of musical works is unsuccessful, this account of creation may be what happens when artefacts such as works of music are created. What is required for the work to exist is for the community to be able to recognise the work (if they are appropriately informed) and use or discuss the work, and to create it requires whatever action puts the community in the position of being able to do this.

\footnotetext{
${ }^{171}$ Howell, 'Types, Indicated and Initiated', pp. 119-120. Howell draws a distinction between properties, types, and patterns, which he sees as an intermediate between the two, but that is not important for the point I am making.

172 ibid., p. 120 ff
} 


\subsection{Individuals}

It seems natural for philosophers to suppose that works of music are types, or kinds, or universals. This is because of the repeatability of musical works. Philosophers who hold this view (both Platonists and modified Platonists) contend that the work is a type (universal) and the performances of it are tokens (instantiations). The repeatability of musical works is an important datum for ontologists of music, so it is something that any theorist on this issue has to respect. ${ }^{173}$ Universals are themselves the topic of much philosophical controversy, so it may be suggested that answering the question of the ontology of works of music by appealing to universals does not make matters so much clearer. However, this is of itself not enough of a reason to reject the view of works of music as types.

A common view of the ontological status of musical works, beginning with Nicholas Wolterstorff, is that they are norm-kinds, as were discussed in the previous section. ${ }^{174}$ On this view, musical works can be performed correctly or incorrectly, and to varying degrees. This is often introduced as a contrast to the views of Nelson Goodman, who held that, for a performance to qualify as a performance of a particular work, it could not have a single wrong note. This view is strongly unintuitive, but Goodman claimed that believing otherwise was untenable. ${ }^{175}$ The reason he has for holding this view is as follows:

\footnotetext{
${ }^{173}$ Julian Dodd seems to suggest that it is the most important intuition, and should be respected above all others. See Dodd, Works of Music, p. 3

${ }^{174}$ Wolterstorff, Works and Worlds of Art, p. 56

${ }^{175}$ N. Goodman, Languages of Art, p. 120
} 
The innocent-seeming principle that performances differing by just one note are instances of the same work risks the consequence-in view of the transitivity of identity - that all performances whatsoever are of the same work. If we allow the least deviation, all assurance of work-preservation and score-preservation is lost; for by a series of one-note errors of omission, addition, and modification, we can go all the way from Beethoven’s Fifth Symphony to Three Blind Mice. ${ }^{176}$

This seems to simply be a case of taking our philosophical theories too seriously and the art that is being discussed not seriously enough. Theories of the ontology of art should not be vastly revisionary of artistic practice, and the claim that it is impossible for a performance of a work to have a single wrong note clearly is revisionary. Goodman's position also makes it much too easy to become a great composer. Because a single different note makes a different work, a new work can be created by adding a note on to the end of an existing (great) work. This consequence is not appealing, because it is an obvious fact that not just anyone can compose a work of genius.

As has been mentioned earlier, Julian Dodd argues that works of music must be kinds. There are difficulties with this view that he attempts to deal with. One problem for Dodd and Wolterstorff is that we hold as true sentences such as (10) Bach's Violin Concerto BWV 1041 ends with an A minor chord. ${ }^{177}$

If Bach’s Violin Concerto BWV 1041 is an abstract object, as Dodd and Wolterstorff think it is, then it cannot be extended in time. On Dodd's view, types are also unstructured, so do not contain notes as parts at all. Because of this, (10) cannot be straightforwardly true: Bach’s Violin Concerto BWV 1041 does

\footnotetext{
${ }^{176}$ ibid., p. 187

${ }^{177}$ Dodd, Works of Music, p. 83
} 
not contain any A minor chords. However, Dodd and Wolterstorff each seek to hold on to the intuition that (10) and other sentences of similar form can be true. To do this, they first note that 'ends with an A minor chord' can be truly predicated of a performance of a work of music. So,

(11) This performance of Bach's Violin Concerto BWV 1041 ended with an A minor chord.

can be straightforwardly true (when the utterer is appropriately situated before a performance of the concerto). The predicate 'ends with an A minor chord' must thus have a different meaning in (10) than in (11) for both sentences to be true. Wolterstorff agrees that the predicate differs in meaning in the two sentences, but claims that there is a 'systematic relation' between them. ${ }^{178}$ The relation is as follows:

Suppose that 'is- $f$ ' is a predicate which can be shared between an art work $W$ and its examples, and suppose further that a property for which 'is- $f$ ' stands when truly predicated of examples of $W$ is being-f. Then for those cases in which the sharing of 'is- $f$ ' fits the general pattern which we formulated, 'is- $f$ ' when truly predicated of $W$ stands for the property of being such that something cannot be a correct example of it without having the property of being-f. Or in other words, it stands for the property of having the property of being- $f$ normative within it. If [ending with an A minor chord] is a property that a sound-sequence-occurrence can have, then to predicate [ends with an A minor chord] of [Bach's Violin Concerto BWV 1041] is not to claim of [Bach's concerto] that it has that property. It is rather to claim that that property is normative within [Bach's concerto]. ${ }^{179}$

\footnotetext{
${ }^{178}$ Wolterstorff, Works and Worlds of Art, p. 58

${ }^{179}$ ibid., pp. 61-62
} 
The sharing of predicates between works of music and performances is thus an example of what Wolterstorff calls 'analogical predication' ${ }^{180}$ Predicates which are normally understood to be shared between works of music and their performances and that literally apply to any correct performance apply, by analogy, to the works themselves. The notion of analogical predication is used by Dodd to meet objections which suggest that certain claims we make about works of music (such as (10)) are incompatible with Platonism about works of music. He can retain an account according to which works of music are unstructured while allowing that statements which appear to imply that they are structured are true. However, it is still notable that Dodd's view requires predicates in sentences such as (10) to have other than their usual meanings, and this is a cost (though Dodd believes a minor one) of the Platonist view.

Abstract objects are generally taken to be unable to enter into causal relations. Works of music are generally taken to be able to be heard. Hearing seems to require a causal relation. This is a problem for the view that works of music are types. (Audibility is also a problem for the view that works of music are concrete objects, but for different reasons.) One option for the Platonist about music to take is to claim that works of music cannot be heard, but that only performances of them can. However, most Platonists are unwilling to take this step. As Dodd writes: 'We hear works performed; we do not merely hear performances of them. Someone who had clearly listened attentively to a performance of In This House, On This Morning, but who nonetheless insisted that she had never heard the work,

${ }^{180}$ ibid., p. 58 
would be looked upon with bewilderment by her fellow concert-goers. ${ }^{, 181}$ An account is therefore required of how this abstract object can be audible. Dodd provides such an account. The claim that he makes is that we can hear a work of music because we can hear the performances (tokens) of it: 'A work of music ... can enter into causal relations derivatively by virtue of being a type of soundevent: a type whose token events can feature as relata of causal relations. Hence, given that the objects of perception are just those things that causally effect how things perceptually seem to us, this means that the type/token theory is not precluded from saying that works of music, in addition to their tokens, may be heard. ${ }^{, 182}$ Levinson makes a similar point from within an indicated type account, by claiming that we hear a sound-structure-as-indicated-by- $X$-at- $t$ by hearing an instance of the sound structure produced by performers who are guided by the composer's indication of it. ${ }^{183}$

David Davies has argued against Dodd by claiming that an entity to which predicates ascribing sonic properties apply only analogously cannot be literally audible. ${ }^{184}$ This may not seem to be a problem: we do not tend to think of Platonic objects as being literally audible. However, Dodd believes that the audibility of musical works is evidence in favour of treating the type/token view as the default view of the ontological status of musical works: 'Musical works, besides being repeatable, are also audible. When listening to a performance of a work of music, one thereby listens to the work performed... A further benefit of the type/token theory is that it smoothly explains how such indirect listening is

\footnotetext{
${ }^{181}$ Dodd, Works of Music, pp. 12-13; Wolterstorff, Works and Worlds of Art, pp. 40-41

${ }^{182}$ Dodd, Works of Music, p. 16

${ }^{183}$ Levinson, 'What a Musical Work Is', p. 27

${ }^{184}$ David Davies, 'Dodd on the 'Audibility' of Musical Works', British Journal of Aesthetics, vol. 49, no. 2, April 2009, pp. 99-108
} 
possible..., ${ }^{185}$ If Dodd's theory implies that works of music are only audible in an analogous sense, the claim that the audibility of works of music is evidence for Platonism will be undercut. Davies claims that, on Dodd's view, the audibility of a work of music just consists in all of the instances of the work being audible. However, any view of the ontology of music will recognise that all instances of a work of music (that is, performances) are audible. ${ }^{186}$ It would beg the question in favour of Dodd's view to claim that all instances of a work of music are tokens of a type in what Davies calls a 'metaphysically freighted sense'. ${ }^{187}$ If works of music only have audibility analogously, then, their audibility cannot count as evidence for the type-token theory ahead of other views of the ontological status of musical works. This is not a knock-down objection to Platonism about musical works, but does serve to seriously weaken the motivation for the view.

There are further reasons for doubting that works of music can be types. One of the most important of these is that works of music are modally flexible, but types are not. ${ }^{188}$ To say that something is modally flexible is to say that it (the very same object) could have been intrinsically different, or different 'in and of itself'. ${ }^{189}$ It certainly seems intuitively true that many works of music could have been different than they are. For instance, ‘Bruckner’s Ninth Symphony might have been finished had he lived longer'. ${ }^{190}$ This sentence is meaningful, and would generally be held to be true by those engaged in critical discussions of

\footnotetext{
${ }^{185}$ Dodd, Works of Music, p. 11

${ }^{186}$ D. Davies, 'Dodd on the 'Audibility' of Musical Works', pp. 104-105

187 ibid., p. 105

${ }^{188}$ Rohrbaugh, ‘Artworks as Historical Individuals’, p. 181

189 ibid.

190 ibid., p. 182
} 
music. The claim that it makes is that a certain work of music could have been different, because finished. If types are modally inflexible, Bruckner’s Ninth Symphony must not be a type. Analogous claims can of course be made for any work of music: the work could have differed by a few notes here and there while remaining the very same work. Platonists about works of music are forced to claim that in such examples the works that we would ordinarily consider to be modified or completed works of music are in fact different works. Dodd at this point bites the bullet, but claims that 'none of this is so counter-intuitive as to undo all the good work that the type/token theory has done up to now. ${ }^{, 191}$ It in fact seems highly revisionary of ordinary critical practice regarding music to treat works as modally inflexible, and critical practice should be the primary guide to the ontological status of works of music.

Guy Rohrbaugh claims that there is another difference between works of music (or other repeatable works of art) and types: works of music are temporally flexible. ${ }^{192}$ An object is temporally flexible 'if and only if it is subject, in principle, to change in its properties over time'. ${ }^{193}$ Rohrbaugh is concerned to draw analogies between different kinds of works of art, and takes it as clear that a painting can change its properties over time, for instance by having the paint fade. It is less immediately clear how a work of music could change: it seems that once the composer has created it, how it is has been determined for good. Rohrbaugh does note the intuitive pull of this idea, but argues that musical works should be able to treated like any other works of art, and that 'a general framework which

\footnotetext{
${ }^{191}$ Dodd, Works of Music, p. 91

${ }^{192}$ Rohrbaugh, 'Artworks as Historical Individuals', p. 186

193 ibid., p. 186
} 
allows for the possibility of change in all artworks is the more powerful one' ${ }^{194}$ Though the idea of a unified ontology of art is an appealing one, it seems question-begging to appeal to such when making substantive claims, such as the claim that musical works are temporally flexible. Rohrbaugh does make an attempt to explain how musical works could be temporally flexible even though our intuitions would suggest that they are not. The suggestion he makes is that the existence of a notational system which allows musical works to be scored prevents works of music from changing over time, in a similar way to how a glass case may prevent a painting from changing. ${ }^{195}$ Thus, most musical works do not, as a matter of fact, change over time (though they may, if the composer revises them after they are completed), though it is still in principle possible for this to happen. However, there can be responses made to the claim that works of music are temporally flexible. Dodd argues that it is more plausible to think of purported cases of a work of music changing as cases where a composer produces a new version of the piece of music (which to Dodd is a distinct work of music, though one in most respects similar to the original). ${ }^{196}$ This account seems to meet our intuitions at least as well as Rohrbaugh's. Dodd also claims that when an object changes, the object as it was before the change no longer exists, and, as the original work of music continues to exist (continues to be performable) after it has been revised, it cannot be considered to be an earlier temporal stage of the same object. ${ }^{197}$ Because of this, it is in fact impossible for a work of music to change with respect to its intrinsic properties over time, and Rohrbaugh's appeal to the temporal flexibility of works of music fails. However,

\footnotetext{
194 ibid., p. 188

195 ibid., p. 188

${ }^{196}$ Dodd, Works of Music, p. 88

197 ibid.
} 
his claim that they are modally flexible is enough on its own to show that works of music are not types.

John Dilworth has raised a further problem for indicated type theories about works of music. He calls this the 'type specification problem' ${ }^{198}$ According to Levinson, sound structures exist at all times. These types do not have any musical properties until they have been indicated by a composer at some time. Dilworth claims that it is necessary for an indicated type theory to be able to tell us precisely which type has been indicated: 'If more than one were indicated, or it turned out to be trivial or arbitrary which one was, then, indication of a particular type as such would be explanatorily irrelevant to the logical and ontological issues concerning the creation and individuation of musical works'. ${ }^{199}$ Unless an indicated type theory can tell us exactly which type has been indicated, it cannot help us see which object the work of music is. Dilworth contends that indicated type theories cannot do this. The first option for an indicated type theorist is to suggest that the sound-structure (type) that has been indicated is one whose tokens are identical to each other. However, the suggestion that the type which has been indicated is fully determinate, as it must be on that account, is far too restrictive. The reason for this is that if all tokens of the low-level type are sonically indistinguishable, then all tokens of the indicated type will be as well. ${ }^{200}$ This precludes any token sound-event that is not identical to the token sound-event that was the proximate cause of the composer's indication from being an instance of the work. As it is widely agreed that

\footnotetext{
${ }^{198}$ John Dilworth, 'Reforming Indicated Type Theories', British Journal of Aesthetics, vol. 45, no. 1, Jan. 2005, p. 15

199 ibid.

${ }^{200}$ ibid.
} 
performances can have wrong notes, this option is unsuccessful. If, however, the indicated type theorist wants to suggest that tokens of the indicated type may be allowed to vary in some of their properties, they run into different problems. The most important of these is that there cannot then be a single sound-event type indicated by the composer. ${ }^{201}$ There will in fact be an infinite number of slightly different sound structures that could each be tokened by a legitimate performance of the work. If this is the case, then it does not seem that there is any way for us to know which sound structure the composer was indicating, and thus which object the work of music is. This problem cannot be solved by arguing that the relevant type is the one which matches the correct performance-tokens, because, prior to the act of indication, there is no musical work, and thus no possible performances, correct or incorrect. ${ }^{202}$ Dilworth thus concludes that indicated type theories are fundamentally flawed.

A major difficulty for the view that works of music are not types but individuals is to account for the fact that there can be many performances of the same work. It is not obvious how to account for the repeatability of musical works while maintaining that they are individuals, not types. Rohrbaugh suggests that the performances of a work of music are not instances of the work, but occurrences of it. ${ }^{203}$ On Rohrbaugh's view, 'occurrence of' is a relation between two individuals: the performance and the work. Performances of a work of music are a subclass of the embodiments of the work of music. Rohrbaugh writes that '[i]t is the job of the 'occurrence of' relation to pick what we care about out from the

\footnotetext{
201 ibid., p. 16

202 ibid., pp. 16-17

${ }^{203}$ Rohrbaugh, ‘Artworks as Historical Individuals’, pp. 197-198
} 
historical flow which sustains the objects'. ${ }^{204}$ What this is saying is that occurrences (in the case of works of music, performances) are the way in which what interests us about the work is presented: 'The 'occurrence of' relation is then a more specific form of the embodiment relation, one conditioned by the needs of the practice of a particular art form and one which picks out those embodiments which display the qualities of the work of art and are relevant to appreciation and criticism. 205 They are not identical to the work, because a work of music has many properties that a performance of it does not. However, they present the salient features of the work's sound to an audience, and allow many of the critical judgements that are made of music to be made. How does this help answer the question of how a work of music, which is an abstract object, can be heard? The work is not identical to the performance, but the performance is part of the class of things on which the work ontologically depends. This is not enough, because the work also ontologically depends on (for instance) the printing of scores for the work, but hearing this happening would not count as hearing the work. If 'performance of' is a relation, and performances present the qualities of the work with which critics are interested, then it seems uncomfortably like a brute fact that we can hear a work (which is abstract) by hearing a performance. However, the postulation of brute facts is not as much of a problem as it may seem. If we are studying our ordinary critical practice to find out what works of music are like, and our ordinary practice tells us that we can hear a work of music by hearing a performance, then it must be so. If works of music are abstract, then, they are the kind of abstracta that can be heard whenever a performance of them is heard.

\footnotetext{
${ }^{204}$ ibid., p. 198

205 ibid.
} 


\section{Works of Fiction}

\subsection{Existence}

Unlike fictional characters, fictions are commonly thought to exist. Anyone who is a realist about fictional characters or works of music because of the fact that we refer to them and quantify over them will doubtless accept the existence of works of fiction as well. Anti-realists about fictional characters and works of music are also likely to be realists about fictions. In fact, many attempts to account for the purported non-existence of fictional characters implicitly rely on the assumption that fictions exist, which tends to be taken for granted. Any ‘According to the fiction' locutions (that are taken to be true) presuppose that there are fictions, as does the prefix fictionalist account. In fact, fictionalists (at least prefix fictionalists) about any domain would seem to presuppose that the fictions which they use to analyse the claims of that domain exist. Realists and anti-realists about other abstract works of art would thus seem to share the belief that fictions exist.

There are reductionist views about works of fiction. Nominalists seek to reduce works of fiction to some concrete objects. One way to do this is to treat a work of fiction as the set of concrete copies of a text. However, it is clear that the set of copies of a work of fiction cannot be identified with the work. A work of fiction does not grow when new copies are printed, or shrink when they are destroyed. Sets also contain their members essentially, whereas it is not the case that a work of fiction would not have existed had some of the copies of it never been printed. 
Identifying a work with the set of its copies gets the order of explanation backwards. Copies are copies of the work, and they can be identified as such (even if they contain minor errors). We cannot see whether two copies are copies of the same work by seeing if they are members of the appropriate set - they are members of the appropriate set because they are copies of the same work. This is analogous to the case of music, where we group performances according to which work they are of, instead of finding the work by considering the set of performances. However, the analogy is not exact, because musical scores are more like instructions and manuscripts (the concrete objects that are copied to produce works of fiction) are more like prototypes. Whether something is a copy of a particular work of fiction depends on its causal history. For a book to be a copy of a particular work of fiction, it must be intended to be a copy of that work, and be produced by copying (or copying a copy of, or ...) whatever concrete object originally grounded what the work is like (presumably the author's manuscript). ${ }^{206}$ This allows for copies produced from divergent chains to count as copies of the same work of fiction, as long as the causal origin is the same. ${ }^{207}$ There may be cases where this conditional is met but there is such a radical failure to copy the work accurately that it does not intuitively seem to be a copy of the work that has been produced. Because we do not in practice have strong intuitions about how accurate a purported copy of a work of fiction must be to count as a copy (and because our practices are the best evidence we have to go by), we may have to just admit that there are fuzzy cases. It does not seem that this does any damage to the arguments given here.

\footnotetext{
206 Thomasson, Fiction and Metaphysics, pp. 64-65

207 ibid.
} 
A different reductionist theory is action theory, according to which works of fiction are (either type or token) actions by authors. David Davies ${ }^{208}$ and Gregory Currie $^{209}$ are two action theorists about works of fiction. Currie’s view that a work of art is a compositional action is compatible with his speech-act definition of fiction. ${ }^{210}$ In trying to provide a definition of fiction in terms of what kind of speech act (or illocutionary action) the author is performing, Currie follows John Searle. ${ }^{211}$ Searle's view is that a work of fiction is not a speech act at all. The author of a work of fiction is, in writing the work of fiction, pretending to make assertions. It is a pretended illocutionary act (though a real utterance act). The major reason that Searle gives for thinking that the author of a fiction is not performing an illocutionary act is that which illocutionary act the utterance of a sentence performs depends on the meaning of the sentence. ${ }^{212}$ If writing a fiction is a distinct illocutionary act from making an assertion, then (on Searle’s view) the meaning of a sentence used in a work of fiction must be different than the meaning of the same sentence when it is used to make an assertion. Searle writes that this means that anyone who argues that writing fiction is a distinct illocutionary act is:

committed to the view that words do not have their normal meanings in works of fiction. That view is at least prima facie an impossible view since if it were true it would be impossible for anyone to understand a work of fiction without learning a new set of meanings for all the words and other elements contained in the work of fiction, and since any sentence whatever can occur in a work of fiction, in order to have the

\footnotetext{
${ }^{208}$ D. Davies, Art as Performance

${ }^{209}$ Currie, An Ontology of Art

${ }^{210}$ Gregory Currie, 'What is Fiction?', Journal of Aesthetics and Art Criticism, vol. 43, no. 4, Summer 1985, pp. 385-392

${ }^{211}$ John Searle, 'The Logical Status of Fictional Discourse', New Literary History, vol. 6, 19741975, pp. 319-332. Another notable discussion of fiction in terms of illocutionary actions is Monroe C. Beardsley, 'Fiction as Representation', Synthese, vol. 46, no. 3, March 1981, pp. 291313

212 ibid., p. 324
} 
ability to read any work of fiction, a speaker of the language would have to learn the language all over again, since every sentence in the language would have both a fictional and a nonfictional meaning. ${ }^{213}$

Searle then goes on to give a positive definition of fiction. He claims that the author of a work of fiction is engaged in a 'nondeceptive pseudoperformance which constitutes pretending to recount to us a series of events'. ${ }^{214}$ The words used in a work of fiction have their ordinary meanings, but there are conventions of fiction which remove the ordinary commitments that are required by these meanings. ${ }^{215}$ This view has an obvious disadvantage: in order to keep fictional and non-fictional meanings identical, it requires us to accept that the way language is used in fiction is of a completely different kind to the way it is used otherwise. The conventions that Searle invokes seem to add a degree of difficulty to our reading of fiction which is not in fact present.

Currie rejects Searle's arguments, and claims that fiction-making is itself a distinct illocutionary act. Currie correctly points out that the author of a work of fiction is not pretending to do anything, but is really performing the act of making a work of fiction. Currie argues that in order to be making a work of fiction (performing the illocutionary act of fiction-making), the author must produce an utterance that he intends readers to make-believe. ${ }^{216}$ Furthermore, at least part of the reason for readers to make-believe the utterance is the recognition that the author intends them to do this. ${ }^{217}$ This account is more successful than Searle's pretended utterance account. The author is performing

213 ibid.

214 ibid., p. 325

215 ibid., p. 326

${ }^{216}$ Currie, 'What is Fiction?', p. 387

${ }^{217}$ ibid. 
an action of making a fiction, with the intent that the audience will treat it as a work of fiction. On the action theory view, the fiction is in fact the act of producing the utterance, and not the utterance (qua object) itself (hence the compatibility between Currie’s two views). However, Currie’s account can still serve as an acceptable definition of fiction even if we regard the utterance qua object, and not the performance, as the fiction. It seems intuitively clear that we do not treat a work of fiction as the performance of creating it: when we read a book, we do not consider ourselves to be gaining access to the author's action of writing it (at least, this is not our primary interest).

\subsection{Creation}

As we have seen before, the claim that abstract objects such as fictions can be created is controversial. Deutsch’s ‘creation problem’ can again be taken to apply to works of fiction. ${ }^{218}$ The argument, briefly, is that fictions are abstract objects, and abstract objects are generally held to exist necessarily. This means that it is impossible to create abstract objects. Anyone who holds this view will need to argue that, contrary to our intuitions, authors select, and not create, their fictions. The responses to be made to this argument in the case of works of fiction will be similar to those in the cases of fictional characters and works of music.

To deny the first premise of Deutsch's argument (that fictions are abstract objects) would be to claim that fictions are concrete objects. The most plausible way to

${ }^{218}$ Deutsch, 'The Creation Problem', p. 210 
do this is to suppose that fictions are copies (or sets of copies) of the fiction. This nominalistic strategy fails, for reasons given earlier. Anyone who does accept that works of fictions are concrete objects in this way would have to accept that works of fiction are created. It is uncontroversial that (concrete) books can be created, so denying the first premise of Deutsch’s argument will not help the anti-creationist.

Like in the cases of music and of fictional characters, the third premise of Deutsch's argument can be denied. This is to claim that works of fiction can stand in causal relations, and so can be created. That works of fiction are created is the view that will be defended here.

A reason for thinking that works of fiction are created is that creationism about fictions allows us to individuate fictions in an intuitively correct way. The cases that illustrate this point are the cases which show that the same text can be the text of different fictions. The most famous of these is Borges's Pierre Menard case. In the philosopher's version of this story, Menard writes a text which is word-for-word identical with Don Quixote. ${ }^{219}$ However, Menard's work is a different work to Cervantes’s, because it has radically different (aesthetic) properties. Arthur Danto writes that Borges made a 'stupendous' contribution to the ontology of art, by showing that a work's location in the history of literature and relationship to its author 'penetrate[s], so to speak, the essence of the work' ${ }^{220}$ If Danto is correct here, works of fiction cannot be eternally existing

\footnotetext{
${ }^{219}$ In Borges's story, Menard actually sets out to write (but not copy) Don Quixote, and manages to complete two chapters from different parts of the book.

${ }^{220}$ Arthur C. Danto, The Transfiguration of the Commonplace (Cambridge, MA: Harvard University Press, 1981), pp. 35-36
} 
abstracta. This is because eternally existing abstracta are not located in the history of literature or related to their authors. Because the philosopher's version of the story is arguably not entirely true to Borges’s story, ${ }^{221}$ Gregory Currie has invented another example to make the same point. In Currie’s thought experiment, Jane Austen and Anne Radcliffe each produce identical texts, titled 'Northanger Abbey'.222 Radcliffe’s (hitherto unknown) piece was written ten years earlier than Austen's, and was intended to be a genuine contribution to the genre of Gothic novels. Austen’s piece was a burlesque of the Gothic novel. ${ }^{223}$ The two pieces have different properties. Austen’s work has implicit references to other works in the genre, but Radcliffe's does not (Radcliffe's work was written earlier than some of them). There is irony to be found in Austen's work that is not there in Radcliffe's. ${ }^{224}$ This is supposed to be a case in which there are two works (of fiction) but only one text.

If there are two works in this case, but only one text, there must be something that grounds this difference. The two have different aesthetic properties, but this is not quite enough. The difference in aesthetic properties comes from the fact that it is appropriate to interpret the two works differently. However, the fact that it is possible to interpret two word-for-word identical works differently is not enough to explain what it is that makes the two different. It is of course possible (as Borges reminds us in his Pierre Menard story) to interpret one work in two (or more) different ways, but this does not seem to imply that this work is in fact

\footnotetext{
${ }^{221}$ See B. R, Tilghman, 'Danto and the Ontology of Literature', Journal of Aesthetics and Art Criticism, vol. 40, no. 3, Spring 1982, pp. 293-299, and Deutsch, 'The Creation Problem', pp. 224-225

${ }^{222}$ Gregory Currie, 'Work and Text', Mind, N.S. Vol. 100, No. 3, July 1991, p. 328

${ }^{223}$ ibid.

${ }^{224}$ ibid., pp. 328-329
} 
two works. In fact, if different possible interpretations make different works, then any moderately or highly complex work of fiction will not be a single work at all, but a number of different (but textually indiscernible) works. This is strongly counterintuitive. We believe that, for instance, Henry James's The Turn of the Screw is just one work of fiction, even though two distinct interpretations of it are available (either the governess is really seeing ghosts or she is imagining it). Because of this, different interpretations are not enough to imply that there are different works. There must therefore be some additional reason that it is appropriate to interpret Austen's and Radcliffe’s works differently, if they are taken to be different works. The most plausible reason is that the two originate in different acts of creation. Austen created a different work than Radcliffe created, and it is because of this that the two have different aesthetic properties. This seems to have the order of explanation right. Although it may be because of the differences in aesthetic properties that we know that the two are different works, these properties are not prior to the creation of the work. It is the work as created by its particular creator that grounds the aesthetic properties in question. Works of fiction, then, must be created if our ordinary practices of individuating works from each other are to be sustained.

A modified Platonist attempt to account for the creation of works of fiction is Jerrold Levinson's view that works are 'indicated types'. This is analogous to his view of musical works (and can be held for similar reasons). ${ }^{225}$ On this account, a work of fiction is a word structure-as-indicated-by- $X$-at- $t$, where $X$ is the author

${ }^{225}$ Levinson, 'What a Musical Work Is’ 
of the work and $t$ is the time at which he creates it. ${ }^{226}$ This strategy fails to account for the creation of works of fiction for the same reason that it fails to account for the creation of works of music. The problem is that a word sequenceas-indicated-by- $X$-at- $t$ is not a distinct object from the word sequence (which Levinson takes to pre-exist the author's action). Indicating a pre-existing type may be enough to move some entity (the type) from one ontological category to another (from 'pure word sequence' to 'work of fiction'), but is not enough to literally create anything. Furthermore, if types (word sequences) are not creatable, which Levinson grants (hence the need for the new ontological category of indicated types), and indicated types are types (as they seem to be, given that they have the properties that suggest that works of fiction may be types, such as repeatability), then indicated types are not creatable either. If indicated types are not creatable, then they fail to satisfactorily account for our beliefs about works of fiction, and if they are not types then their claim to the advantages of type theories appears questionable. Treating works of fiction as indicated types is thus unsuccessful.

Works of fiction are created when authors perform certain acts (writing and having published pieces of fiction) within a certain cultural context. This is a sign of the dependence of fictional works on mental states. They are dependent on the particular acts of their particular authors. ${ }^{227}$ Without these acts (and not some other acts somewhat like them), a particular work of fiction could not have come into existence. They are also dependent on there being an appropriate context of

\footnotetext{
${ }^{226}$ Jerrold Levinson, 'Autographic and Allographic Art Revisited', Philosophical Studies, vol. 38, no. 4, Nov. 1980, p. 373

${ }^{227}$ Thomasson, Fiction and Metaphysics, p. 36
} 
reception for the works. ${ }^{228}$ This context includes there being someone capable of understanding the language of the work, and also having our practices of dealing with works of fiction. The dependence on context of reception is a generic dependence because works are dependent merely on there being some reader located in an appropriate context of reception, not on any particular reader. ${ }^{229}$ Like other works of art and other abstract artefacts, works of fiction are multiply dependent. They cannot come into existence without their acts of creation, and cannot continue to exist without the continuation of the practices that allow us to know that they exist.

These considerations should allow us to find out when it is that a work of fiction has been created. Unsurprisingly, the answer is similar to that in the case of fictional characters. A work of fiction exists from no later than the time at which we can direct our critical practices towards it (or the time at which we can read it). This is so because it is these critical practices that allow us to infer that the work exists. The time at which we can direct critical practices toward the work is the time at which it becomes publicly accessible, which is the time that it is published. Works of fiction thus come into existence at (or no later than) the time that they are published.

The view of the existence conditions for fictions given here is rather similar to that suggested by Peter Lamarque:

Literary works are cultural objects, dependent on a practice governed by social conventions concerning the production and reception of texts. As they owe their nature and existence to the practice, should the practice cease (the conventions

\footnotetext{
${ }^{228}$ ibid. ${ }^{229}$ ibid.
} 
be lost) literary works themselves would go out of existence, even though the texts remain. ${ }^{230}$

On this view, the existence of fictional works comes out of our practices of dealing with fictional texts, much like Stephen Schiffer ${ }^{231}$ argues with regards to fictional characters. This means that works of fiction are not mind-independent. Even if texts can exist mind-independently (and it is surely true that copies of our works of fiction could continue to exist if there were no humans), works of fiction require people with particular social conventions. Furthermore, what works of fiction are like is determined (and created) by these conventions.

\subsection{Individuals}

Fictions seem far more amenable than fictional characters to being treated in type/token terms. This is because fictions, like works of music, seem to be repeatable. Many different physical objects (generally books, but possibly also spoken utterances or even audio recordings) can be copies of the same fiction. The copy of Alice's Adventures in Wonderland on my bookshelf is a copy of the same work of fiction as other copies elsewhere. The type/token view would see any (correct) copies of a fiction as tokens of the abstract type (word sequence) with which the fiction is to be identified. However, as Danto notes, this could apply to any texts, whether works of fiction or government pamphlets. ${ }^{232}$ Repeatability is a property shared by fictional and non-fictional works, whether or not there are other such properties as well.

\footnotetext{
${ }^{230}$ Peter Lamarque, 'Objects of Interpretation', Metaphilosophy, vol. 31, no. 1-2, Jan. 2000, p. 105

${ }^{231}$ Schiffer, 'Language-Created Language-Independent Entities’, pp. 156-157

${ }^{232}$ Danto, The Transfiguration of the Commonplace, p. 34
} 
Fictions are taken by some philosophers to be norm-kinds. Norm-kinds are kinds which can have both correct and incorrect instances. ${ }^{233}$ This allows for copies of a fiction which contain misprints to still count as genuine copies of the fiction. It is clearly the case that copies of a fiction can contain misprints without losing their identity, so a view of this kind has a clear advantage over a pure Platonist or Goodman-style nominalist account that did not allow for this, as has been discussed in the previous chapter.

A common topic of discussion in the ontology of fiction is whether the work is identical to the text. A text should be understood as a particular sequence of words. It sometimes seems to be assumed that word sequences, and thus texts, are eternally existing abstracta, or types. It is not entirely clear that we should believe that they are. Given that it seems impossible for words to exist eternally and necessarily, ${ }^{234}$ it doesn't seem as if sequences of words should either. Maybe it is the case that once the words exist, the word sequences are an ontological free lunch. Texts thus do not exist eternally or necessarily, but do exist as long as the relevant words exist. This is enough for them to exist before any works of fiction do. ${ }^{235}$ Type/token theorists generally argue that the text is identical to the work, or is (at least) a necessary part of the work. Those who believe that fictions are individuals will want to argue that the text and the work are distinct. Part of the reason for thinking they are distinct is that it is the work that we are interested in.

\footnotetext{
${ }^{233}$ Nicholas Wolterstorff, Works and Worlds of Art, p. 56

${ }^{234}$ David Kaplan, 'Words', Proceedings of the Aristotelian Society Supplementary Volume, vol. 64,1990 , pp. 93-119, provides an account of words as created objects, or artefacts, which is also similar to the accounts of works of art given here.

${ }^{235}$ Levinson, 'Autographic and Allographic Art Revisited', p. 373, also suggests this.
} 
Readers and critics have to take themselves to be reading a work, not (merely) a text, in order to interpret the work.

Amie Thomasson draws a threefold distinction between texts, compositions, and works:

By "text” I mean a sequence of symbols in a language (or languages); by “composition” I mean roughly the text as created by a certain author in certain historical circumstances; by "literary work" I mean roughly the novel, poem, short story, or so forth having certain aesthetic and artistic qualities and ordinarily telling a tale concerning various characters and events. ${ }^{236}$

Though I will not be using the term 'composition', the definitions Thomasson gives for 'text' and 'work' are substantially similar to those used here.

An option for anyone who thinks that works of fiction are types is to treat works of fiction purely syntactically, that is, purely as sequences of line-shape types, as suggested by Yagisawa. ${ }^{237}$ Yagisawa writes that

The story A Study in Scarlet is a collection of English sentences, which Doyle wrote in 1886. English sentences are sequences of English words in conformity with the syntactic rules of English. English words are those sequences of letters which are included in the vocabulary of English. The vocabulary of English is a finite list of sequences of letters from the English alphabet. A sequence of sequences of things is a sequence of those things. So, the literary work, A Study in Scarlet, is a collection of sequences of the letters of English alphabet in conformity with certain syntactic rules. As such, the work is at least as abstract as any sequence of letters, which in turn is at least as abstract as the letters. The letters are abstract line-shape types. So the work is at least as abstract as lineshape types. Line-shape types, like any type, may be instantiated. To write $A$

${ }^{236}$ Thomasson, Fiction and Metaphysics, p. 64

${ }^{237}$ Yagisawa, 'Against Creationism in Fiction', p. 168 
Study in Scarlet is to produce an instance of the sequence of the line-shape types that is the story without copying another such instance. ${ }^{238}$

Goodman and Elgin make a similar claim to Yagisawa, by arguing that identity of a text is a purely syntactic matter, and not related to what the text says or means or refers to. ${ }^{239}$ Furthermore, they argue that works are identical to texts. On Goodman and Elgin’s interpretation, Pierre Menard (in Borges’s case) has not created a work at all. He has merely produced a replica of Cervantes's text without copying it, and given us a new way of interpreting the work ('as a contemporary story in an archaic style with a different plot'). ${ }^{240}$ Neither of these achievements, according to Goodman and Elgin, counts as creating a new work. Menard's writings are just another instance of Cervantes’s text, along with every copy ever printed of it. Even an inscription identical to Don Quixote but produced randomly would count as an instance of Cervantes's text (work). ${ }^{241}$ Unlike on artefactualist views, the intentions of the author play no part in individuating works on this view. It is even possible for texts (and therefore works) to be produced by machines that do not understand what they are writing. Works produced in this way will still have all of the same interpretations as they would have if they were consciously written by authors.

There are problems for this view. One of these is that it makes it hard to see how a translation of a work can be an instance of the same work of fiction. Certainly a translation of a fiction will be comprised of a vastly different sequence of line-

\footnotetext{
${ }^{238}$ ibid., pp. $167-168$

${ }^{239}$ Nelson Goodman and Catherine Z. Elgin, 'Interpretation and Identity: Can the Work Survive the World?' in Goodman and Elgin, Reconceptions in Philosophy \& Other Arts \& Sciences

(Indianapolis and Cambridge: Hackett Publishing Company, 1988), p. 58

${ }^{240}$ ibid., p. 62

241 ibid.
} 
shape types, but it still seems that it is the same work. This point is disputed by Goodman and Elgin. They agree that translations would be a problem for this claim if the translation of a work was identical to the original work. ${ }^{242}$ However, they do not think that work-identity is preserved:

Obviously no translation retains all that is significant in the original. Even if the two are coextensive, reporting exactly the same events in as closely as possible the same way, they will somewhat differ in meaning...Indeed, the translator of a poem typically has to decide the relative importance of preserving denotation (what the poem says), exemplification (what rhythmic, melodic, and other formal properties it shows forth), and expression (what feelings and other metaphorical properties it conveys). ${ }^{243}$

It has been argued that this claim works against the view that Goodman and Elgin themselves propose. They claim that texts are individuated solely by their spelling, so that 'The cape is beautiful' is just one text even if it is used at different times to refer to an item of clothing and a geographical feature. However, if Goodman and Elgin accept cases like this, where a single text (on their account) can have a radically different meaning, then there seems to be no reason to treat translations as different works just because something is lost in translation. ${ }^{244}$

A further (and more serious) problem for the view that fictions are sequences of line-shape types is that works of fiction have meanings, and in fact have these meanings essentially. Sequences of line-shape types (pure sequences) do not have meanings at all - they are merely squiggles. Even if it can be argued that

\footnotetext{
242ibid., p. 57

${ }^{243}$ ibid. Goodman did not think that any two expressions were synonymous. People who disagree with this might find it easier to accept translations as the same work.

${ }^{244}$ Robert Schwartz, 'Works, Works Better’, Erkenntnis (1975), vol. 38, no. 1, January 1993, p. 107
} 
such sequences do have meanings, it seems that they have them inessentially. It is an accidental fact that some sequence of line-shape types produces sentences about the doings of a detective in Victorian London. It is not an accidental fact about A Study in Scarlet that it is about the doings of a detective in Victorian London. If it were not about this, it would be a different work of fiction. Because of this, the sequence of the line-shape types is not identical to the work of fiction which is A Study in Scarlet.

A reason that works of fiction cannot be types is that works of fiction are modally flexible. Something is modally flexible if it (the very same thing) could have been different. This seems to apply to fictions. We have the intuition that works of fiction could have been different than they are. For instance, as Rohrbaugh writes, 'Proust's A La Recherche du Temps Perdu could have been longer, shorter, or contained somewhat different sentences than it in fact does. ${ }^{245}$ This is a possibility for that very fiction, and not the possibility that there could have been a different fiction with the same name. This does not conflict with the claim that works of fiction have certain meanings essentially. The fact that (to go back to the previous example) A Study in Scarlet has certain meaning properties essentially does not preclude the possibility of its having some different words. It may suggest that the modal flexibility of works of fiction is not limitless, but, given that we do not ordinarily suppose that it is, this does not create a problem for the artefactualist view.

${ }^{245}$ Rohrbaugh, ‘Artworks as Historical Individuals’, p. 182 
The claim that works of fiction are modally flexible has been argued against by Currie, who writes that:

What is partly constitutive of a given work is its pattern or structure. No theory of art works that made the structure extrinsic or incidental to that work could hope for acceptance. It is not just an accidental fact about Emma that it contains that particular word sequence. ${ }^{246}$

However, this could be seen to be trading on an ambiguity in the word 'accident'. As Rohrbaugh notes, it is no accident that Emma contains exactly that word sequence, 'but this is not a sense of 'accident' which contrasts with 'modally necessary', but with 'deliberate’, ${ }^{247}$ He argues that Jane Austen did deliberately (not accidentally) produce a particular sequence of words, but this does not show that it is necessary that Emma contains exactly that sequence. The modal flexibility of works of fiction also implies (possibly this is the same point) that work and text cannot be identical. As Currie notes, if work and text are identical, then, by familiar arguments, they are necessarily identical. ${ }^{248}$ Because we think that works could have had different texts, the necessity of identity shows that work is not identical to text (though, as just noted, Currie does not believe that works actually are modally flexible).

Rohrbaugh also claims that works of fiction are temporally flexible. ${ }^{249}$ This is more intuitively plausible than the similar claim about works of music. We are familiar with later editions of works which have had (for instances) typographical errors corrected. These appear to be copies of the same work of fiction, but to be different from earlier copies. However, it is not completely clear

\footnotetext{
${ }^{246}$ Currie, An Ontology of Art, pp. 64-65

${ }^{247}$ Rohrbaugh, 'Artworks as Historical Individuals', p. 182

${ }^{248}$ Currie, 'Work and Text', p. 327

${ }^{249}$ Rohrbaugh, 'Artworks as Historical Individuals’, p. 186
} 
that this is an example of a work of fiction changing. It is perhaps more plausible to think that the later editions were correct all along (that is, they contained the text that should have been contained in any copy of the work), and that the earlier editions were in error. The work thus need not change. There are, though, cases where an author revises a work after it has been published. These cases can be seen in either of two ways. They are either cases where a single work changes some of its properties, or cases where a new (but very similar) work is created. There seems to be no strong intuitions to pull us one way or the other on this case (which itself makes the temporal flexibility of works of fiction seem more plausible than the similar claim about works of music).

If works of fiction are not types, then copies of the work do not stand to the work in a type/token relationship. As in the case of music, this fact makes it difficult for anyone who claims that works of fiction are individuals to account for their repeatability, and for the fact that different concrete objects (books) can be copies of the same work. Instead of being tokens of the work, books should be seen as occurrences of it. ${ }^{250}$ In other kinds of art, occurrences are a subclass of the 'embodiments' of a work, where embodiments are the concrete objects on which the work ontologically depends for its nature and continued existence. ${ }^{251}$ In the case of works of fiction, it is not clear that there are any embodiments that should not count as copies. The relationship between an original manuscript and

\footnotetext{
250 ibid., p. 198

${ }^{251}$ Rohrbaugh actually claims that embodiments are the things a work depends on for its continued existence. This isn't quite true. Works of fiction (for instance) also rely on people for their continued existence, but I am not an embodiment of any work of fiction. Maybe my Gorky Park-related thoughts should count as embodiments of Gorky Park, though even this seems to be a stretch. Because of this, I prefer to say that embodiments do not just determine that the work continues to exist, but what the work is like. Rohrbaugh may say this himself too. See ibid. pp. 198, 191
} 
a later printed copy of a work seems different than that between a score and a performance of a work of music. A manuscript is more like a blueprint than a set of instructions, and, unlike a score, is an occurrence of the work. This does not mean that the repeatability of works of fiction requires a different explanation than that of works of music. The 'occurrence of' relation between the work and the things which give us access to the work (generally books) will be similar in each case. What is different about works of fiction is that all embodiments could count as occurrences. Perhaps a film version of a novel would count as an embodiment, but not an occurrence, of the work of fiction. I don't have any real intuitions on whether The Lord of the Rings ontologically depends in any way on the movies based on the book, but I do think that if all traces of the books disappeared then the work would have disappeared even if the films remained. There seems to be more to a work of fiction (language, or style, perhaps) than can be shown in a film. To read an occurrence of a work of fiction (a copy) counts as reading the work. Because copies of the work are embodiments of the (abstract) work, in reading them we have access to the entire work, and can find out what the work is like. This gives artefactualism an advantage over views which claim that a work of fiction is the set of (or the fusion of) copies of the work, as this would mean that we could not access the whole of the work without reading all of the copies. 


\section{Conclusion}

This thesis has given evidence for the claim that works of art are artefacts by discussing two controversial cases of kinds of art works (works of music and works of fiction), as well as fictional characters, and arguing that all three are artefacts. If these difficult cases are examples of artefacts, then easier cases (such as paintings) will be able to be shown to be artefacts as well. However, the arguments of this thesis do not have a claim to completeness. There are many other kinds of repeatable work of art that are not discussed, such as films, photographs, pieces of pop or rock music, cast sculptures, dances, and so forth. It may be that many of the arguments deployed here will also be useful in demonstrating that examples of these paradigmatic kinds of works of art are artefacts as well.

There are three theses distinct to artefactualism about works of art. First, works of art exist. Second, works of art are created. Third, works of art are individuals. It has been argued that each of these claims applies to fictional characters, and once we see why and how this is so, we can also see why and how they apply to the two kinds of works of art discussed here. The way that we can find out that these things are true of fictional characters, works of music, and fictions is by examining our critical practices regarding these things. Our critical and interpretive practices are primary: metaphysics should be guided by our critical practices. Our practices assume the existence of fictional characters, works of music, and works of fiction: we refer to such things and quantify over them. We also treat them as created, not as discovered or selected, and creationism about 
these things allows us to individuate them in the appropriate way. Fictional characters and works of art are not properties or kinds or any other way that things are, but individuals in their own right.

It has been shown that eliminativist, reductionist, and fictionalist views about fictional characters, works of music, and works of fiction fail to meet our beliefs regarding the existence of these things and what they are like. Platonist views fail to account for the creation of fictional characters and of works of art. At least in the case of fictional characters, Platonist views also cannot differentiate them from other kinds of thing. These views also do not allow us to treat works of art as modally flexible, and require us to think of works of art as property-like, rather than as particular individuals.

The most difficult problems for the artefactualist view are to explain how abstracta can be created and how individuals can have multiple occurrences. In the first case, they are created by whatever actions enable us (in the first place) to talk about them. These actions are also the actions that bring it about that there are things that can be truly said about what the character or the work is like. Our ability to truly say things about fictional characters and works of art begins when they become publicly accessible, through publication or public performance or some other means. Solving the second problem requires us to explain the fact that we can have (for instance) different performances of the same work of music without appealing to a type/token relationship. This is a problem which does not apply to fictional characters, so solving it requires an extension of the view of fictional characters defended here. The challenge can be met by appealing to the 
notion of embodiment: occurrences (performances of a work of music or copies of a work of fiction) are those embodiments of the work (physical objects on which a work depends) that present us with those features of the work which are salient to criticism. Furthermore, if we are to regard our practices regarding works as primary, and our practices treat works as repeatable, then it must be the case that works are repeatable.

Let me finish with a speculation. Artefactualism is a theory that may in fact be worth examining with regards to many cultural (or even theoretical) objects outside of art. Most clearly, works of non-fiction seem to have the same relevant properties as works of fiction, and to thus be artefacts as well. Words seem to be an example of created abstracta, and propositions, sentences, and theories may all be such that their nature is determined by our practices of using them, and those practices imply that they are existent, created (and thus at least initially mind dependent), individual objects. Properties could also be relevantly similar as regards their means of creation: they may just come along with our practices of talking about properties. Possible worlds may turn out to be artefacts that are created by philosophers using a certain theory. It is hard to know without further research exactly how far artefactualism in metaphysics can be pushed. There seem to be reasons that are not applicable to fictional characters or works of art for treating such things as possible worlds and properties as eternal or necessary existents. Numbers would seem to be a case where it is highly questionable whether they could be created or whether they would still exist without us. However, it is highly likely that the conclusions drawn here about works of art will have some applications elsewhere. 


\section{Bibliography}

Anderson, James C., 'Musical Kinds', British Journal of Aesthetics, vol. 25, no. 1, Jan. 1985, pp. 43-47

Beardsley, Monroe C., 'Fiction as Representation', Synthese, vol. 46, no. 3, March 1981, pp. 291-313

Brock, Stuart and Mares, Edwin, 'Fictional Characters' in Brock, Stuart and Mares, Edwin, Realism and Anti-realism (Stocksfield: Acumen, 2007), pp. 199220

Brock, Stuart, 'Fictionalism about Fictional Characters', Nous, vol. 36, no. 1, 2002, pp. 1-21

Cameron, Ross P., 'There Are No Things that are Musical Works', British Journal of Aesthetics, vol. 48, no. 3, July 2008, pp. 295-314

Currie, Gregory, An Ontology of Art (New York: St. Martin’s Press, 1989)

Currie, Gregory, The Nature of Fiction (Cambridge: Cambridge University Press, 1990)

Currie, Gregory, 'Review of Music, Art, and Metaphysics', Philosophy and Phenomenological Research, vol. 53, no. 2, June 1993, pp. 471-475

Currie, Gregory, 'What is Fiction?', Journal of Aesthetics and Art Criticism, vol. 43, no. 4, 1985, pp. 385-392

Currie, Gregory, 'Work and Text', Mind, N.S. Vol. 100, No. 3, July 1991, pp. 325-340

Danto, Arthur C., The Transfiguration of the Commonplace (Cambridge, MA, Harvard University Press, 1981)

Davies, David, Art as Performance (Malden, MA: Blackwell, 2004)

Davies, David, 'Dodd on the 'Audibility' of Musical Works', British Journal of Aesthetics, vol. 49, no. 2, April 2009, pp. 99-108

Davies, David, 'The Primacy of Practice in the Ontology of Art', The Journal of Aesthetics and Art Criticism, vol. 67, no. 2, Spring 2009, pp. 159-171

Davies, Stephen, Musical Works and Performances: A Philosophical Exploration (Oxford: Clarendon Press, 2001)

Davies, Stephen, 'Ontologies of Musical Works', in his Themes in the Philosophy of Music (Oxford: Oxford University Press, 2003) 
Davies, Stephen, Themes in the Philosophy of Music (Oxford: Oxford University Press, 2003)

Deutsch, Harry, 'The Creation Problem', Topoi, vol. 10, no. 2, September 1991, pp. 209-225

Dilworth, John, 'Reforming Indicated Type Theories', British Journal of Aesthetics, vol. 45, no. 1, Jan. 2005, pp. 11-31

Dodd, Julian, 'Musical Works as Eternal Types', British Journal of Aesthetics, vol. 40, no. 4, Oct. 2000, pp. 424-440

Dodd, Julian, Works of Music: An Essay in Ontology (Oxford: Oxford University Press, 2007)

Fine, Kit, 'The Problem of Non-Existents I. Internalism', Topoi, vol. 1, 1982, pp. 97-140

Fisher, John Andrew, 'Discovery, Creation, and Musical Works', Journal of Aesthetics and Art Criticism, vol. 49, no. 2, Spring 1991, pp. 129-136

Gaut, Berys and Livingston, Paisley (eds), The Creation of Art: New Essays in Philosophical Aesthetics (Cambridge: Cambridge University Press, 2003)

Goodman, Jeffrey, ‘A Defense of Creationism in Fiction', Grazer Philosophische Studien, vol. 67, 2004, pp. 131-155

Goodman, Jeffrey, 'Where is Sherlock Holmes?', Southern Journal of Philosophy, vol. 41, 2003, pp. 183-198

Goodman, Nelson and Elgin, Catherine Z., 'Interpretation and Identity: Can the Work Survive the World?' in Goodman and Elgin, Reconceptions in Philosophy \& Other Arts \& Sciences (Indianapolis and Cambridge: Hackett Publishing Company, 1988), pp. 49-65

Goodman, Nelson, Languages of Art: An Approach to a Theory of Symbols (New York: Bobbs- Merrill, 1968)

Howell, Robert, 'Types, Indicated and Initiated', British Journal of Aesthetics, vol. 42, no. 2, April 2002, pp. 105-127

Kania, Andrew, 'The Methodology of Musical Ontology: Descriptivism and its Implications', British Journal of Aesthetics, vol. 48, no. 4, October 2008, pp. 426-444

Kaplan, David, 'Words', Proceedings of the Aristotelian Society Supplementary Volume, vol. 64, 1990, pp. 93-119

Kivy, Peter, 'Orchestrating Platonism', in his The Fine Art of Repetition (Cambridge: Cambridge University Press, 1993), pp. 75-94 
Kivy, Peter, 'Platonism in music: A kind of defense', in his The Fine Art of Repetition (Cambridge: Cambridge University Press, 1993), pp. 35-58

Kivy, Peter, 'Platonism in music: Another kind of defense', in his The Fine Art of Repetition (Cambridge: Cambridge University Press, 1993), pp. 59-74

Kivy, Peter, The Fine Art of Repetition (Cambridge: Cambridge University Press, 1993)

Kivy, Peter (ed), The Blackwell Guide to Aesthetics (Malden: Blackwell Publishing, 2004)

Kripke, Saul, Naming and Necessity (Oxford: Blackwell, 1980)

Lamarque, Peter, 'How to Create a Fictional Character', in Gaut, Berys and Livingston, Paisley (eds), The Creation of Art: New Essays in Philosophical Aesthetics (Cambridge: Cambridge University Press, 2003), pp. 33-52

Lamarque, Peter, 'Objects of Interpretation', Metaphilosophy, vol. 31, no. 1-2, Jan. 2000, pp. 96-124

Levinson, Jerrold, 'Autographic and Allographic Art Revisited', Philosophical Studies, vol. 38, no. 4, Nov. 1980, pp. 367-383

Levinson, Jerrold, 'Review of An Ontology of Art', Philosophy and Phenomenological Research, vol. 52, no. 1, March 1992, pp. 215-222

Levinson, Jerrold, 'The Irreducible Historicality of the Concept of Art', British Journal of Aesthetics, vol. 42, no. 4, Oct. 2002, pp. 367-379

Levinson, Jerrold, 'What a Musical Work Is', The Journal of Philosophy, vol. 77, no. 1, January 1980, pp. 5-28

Lewis, David, 'Truth in Fiction', American Philosophical Quarterly, vol. 15, no. 1, Jan. 1978, pp. 37-46

Lewis, David, Counterfactuals (Cambridge: Harvard University Press, 1973)

Lewis, David, On the Plurality of Worlds (Oxford: Basil Blackwell, 1985)

Parsons, Terence, Nonexistent Objects (New Haven: Yale University Press, 1980)

Predelli, Stefano, 'Musical Ontology and the Argument from Creation', British Journal of Aesthetics, vol. 41, no. 3, July 2001, pp. 279-292

Rohrbaugh, Guy, 'Artworks as Historical Individuals', European Journal of Philosophy, vol. 11, no. 2, August 2003, pp. 177-205 
Rudner, Richard, 'The Ontological Status of the Esthetic Object', Philosophy and Phenomenological Research, vol. 10, no. 3, March 1950, pp. 380-388

Schiffer, Stephen, 'Language-Created Language-Independent Entities', Philosophical Topics, vol. 24, no. 1, Spring 1996, pp. 149-167

Schwartz, Robert, 'Works, Works Better', Erkenntnis (1975), vol. 38, no. 1, January 1993, pp. 103-114

Searle, John, 'The Logical Status of Fictional Discourse', New Literary History, vol. 6, 1974-1975, pp. 319-332

Sharpe, R.A., 'Could Beethoven have “Discovered” the Archduke Trio?', British Journal of Aesthetics, vol. 41, pp. 325-327

Stanley, Jason, 'Hermeneutic Fictionalism', Midwest Studies in Philosophy, vol. 25, 2001, pp. 36-71

Thomasson, Amie L., 'Fictional Characters and Literary Practice', British Journal of Aesthetics, vol. 43, no. 2, April 2003, pp. 138-157

Thomasson, Amie L., 'The Ontology of Art' in Kivy, Peter (ed), The Blackwell Guide to Aesthetics (Malden: Blackwell Publishing, 2004), pp. 78-92

Thomasson, Amie L., Fiction and Metaphysics (Cambridge; New York: Cambridge University Press, 1999)

Tilghman, B. R., 'Danto and the Ontology of Literature', Journal of Aesthetics and Art Criticism, vol. 40, no. 3, Spring 1982, pp. 293-299

Trivedi, Saam, 'Against Musical Works as Eternal Types', British Journal of Aesthetics, vol. 42, no. 1, Jan 2002, pp. 73-82

van Inwagen, Peter, 'Creatures of Fiction', American Philosophical Quarterly, vol. 14, no. 4, October 1977, pp. 299-308

van Inwagen, Peter, 'Existence, Ontological Commitment, and Fictional Entities' in Loux, Michael J. and Zimmerman, Dean W. (eds), The Oxford Handbook of Metaphysics (Oxford; New York: Oxford University Press, 2003), pp. 131-157

van Inwagen, Peter, 'Plantinga on Trans-World Identity', in van Inwagen, Peter and Tomberlin, James E. (eds), Alvin Plantinga (Dordrecht: D. Reidel Publishing Company, 1985), pp. 101-120

Walton, Kendall L., 'Restricted Quantification, Negative Existentials, and Fiction’, Dialectica, vol. 57, no. 2, 2003, pp. 239-242

Walton, Kendall, Mimesis as Make-Believe: On the Foundations of the Representational Arts (Cambridge, MA: Harvard University Press, 1990) 
Wolterstorff, Nicholas, Works and Worlds of Art (Oxford: Clarendon Press; New York: Oxford University Press, 1980)

Yagisawa, Takashi, ‘Against Creationism in Fiction', Philosophical Perspectives, 2001, pp. 153-172

Zalta, Edward N., 'The Road Between Pretense Theory and Abstract Object Theory' in Everett, A., and Hofweber, T. (eds), Empty Names, Fiction, and the Puzzles of Non-Existence (Stanford: CSLI Publications, 2000), pp. 117-147 